OPEN ACCESS

Edited by:

Yong Zhu,

East Carolina University,

United States

Reviewed by:

Xinjun Wu,

University of North Carolina at Chape

Hill, United States

Mary E. Ramsey,

University of Texas at Austin,

United States

${ }^{*}$ Correspondence:

Xin Q

qx@ouc.edu.cn

Specialty section:

This article was submitted to Experimental Endocrinology,

a section of the journal

Frontiers in Endocrinology

Received: 15 October 2020

Accepted: 22 March 2021

Published: 23 April 2021

Citation:

Lyu LK, Li JS, Wang XJ, Yao YJ, Li JF, Li Y, Wen HS and Qi X (2021) Arg-Vasotocin Directly Activates Isotocin Receptors and Induces COX2 Expression

in Ovoviviparous Guppies.

Front. Endocrinol. 12:617580. doi: 10.3389/fendo.2021.617580

\section{Arg-Vasotocin Directly Activates Isotocin Receptors and Induces COX2 Expression in Ovoviviparous Guppies}

\author{
Li Kang Lyu, Jian Shuang Li, Xiao Jie Wang, Yi Jia Yao, Ji Fang Li, Yun Li, Hai Shen Wen \\ and Xin $Q i^{*}$
}

Key Laboratory of Mariculture, Ministry of Education, Ocean University of China, Qingdao, China

Oxytocin (OT) is a crucial regulator of reproductive behaviors, including parturition in mammals. Arg-vasopressin (AVP) is a nonapeptide homologous to Arg-vasotocin (AVT) in teleosts that has comparable affinity for the OT receptor. In the present study, ovoviviparous guppies (Poecilia reticulata) were used to study the effect of AVT on delivery mediated by the activation of prostaglandin (PG) biosynthesis via isotocin (IT) receptors (ITRs). One copy each of it and avt and two copies of itrs were identified in guppies. The results of the affinity assay showed that various concentrations of AVT and IT $\left(10^{-6}, 10^{-7}\right.$, and $\left.10^{-8} \mathrm{~mol} / \mathrm{L}\right)$ significantly activated itr1 $(\mathrm{P}<0.05)$. In vitro experiments revealed significant upregulation $(\mathrm{P}<0.05)$ of cyclooxygenase 2 (cox2), which is the ratelimiting enzyme involved in PG biosynthesis, and itr1 by AVT and IT. Furthermore, dual in situ hybridization detected positive signals for itr 1 and cox2 at the same site, implying that ITR1 may regulate cox2 gene expression. Measurement of prostaglandin $F_{2 a}\left(P F_{2 a}\right)$ concentrations showed that AVT induced $\mathrm{PGF}_{2 a}$ synthesis $(P<0.05)$ and that the effect of IT was not significant. Finally, intraperitoneal administration of $\mathrm{PGF}_{2 a}$ significantly induced premature parturition of guppies. This study is the first to identify and characterize AVT and ITRs in guppies. The findings suggest that AVT promotes PG biosynthesis via ITR and that $\mathrm{PGF}_{2 \mathrm{a}}$ induces delivery behavior in ovoviviparous guppies.

Keywords: Arg-vasotocin, isotocin receptor, cyclooxygenase, prostaglandin, parturition, guppy

\section{INTRODUCTION}

Oxytocin (OT) is a highly conserved nonapeptide that was the first peptide hormone with determined molecular structure (1). OT has various effects and is involved in many physiological processes, especially reproduction. In mammals, OT has a notable effect on the induction of parturition and smooth muscle contraction and has been used as a medicine in the clinic (2-5). In teleosts, studies of isotocin (IT), a homolog of OT, have been primarily focused on social behaviors, including social decision-making and anxiety behaviors in mosquitofish (Gambusia affinis) (6), paternal care and social class in cichlid fish species (7-9) and territory defense, egg care and courtship behaviors in three-spined stickleback (Gasterosteus aculeatus) (10). However, the 
mechanism governing the effect of IT on ovulation in oviparous teleosts has not been determined. IT may influence ovulation in teleosts. OT injection in killifish (Fundulus heteroclitus) and seurukan fish (Osteochilus vittatus) induces the spawning reflex $(11,12)$. Injection of a combination of Ovaprim and IT activated ovulation in Hoven's carp (Leptobarbus hoevenii) (13). The functions of IT in the reproduction are limited to the induction of premature parturition in guppy (Poecilia reticulata) (14). Other studies suggested that AVT may also regulate sex-related reproductive behaviors.

Arg-vasotocin (AVT) is the homolog of mammalian Argvasopressin (AVP). AVT functions in various adaptive behaviors are similar to those of IT. AVT is important for osmoregulation (15), and increasing number of neuroanatomical studies reported that AVT is involved in the regulation of sex-related reproductive behavior (16-18). In teleosts, exogenous administration of AVT to peacock blenny (Solaria pavo) induced female courtship behavior and the expression of nuptial coloration (19). Identification of putative functional sites of AVT in the hypothalamic-pituitary-gonad (HPG) axis in chanchita (Cichlasoma dimerus) indicated a positive effect on gonadotropin secretion and on the differences in the social status in males (20).

Both OT/IT and AVP/AVT are nonapeptide hormones produced from a common precursor (21) and share seven out of nine amino acids in their primary structure (22). OT and AVP may bind to each other receptors due to strong similarity of their chemical structures (22). A study in Wistar rats demonstrated that peripheral administration of both OT and AVP induced profound effects manifested as a reduction in body temperature and heart rate, and these changes were predominantly mediated by the AVP V1a receptor (V1aR) (23). Peripheral administration of the OT and AVP neuropeptides induced prosocial effects that were prevented by an oxytocin receptor (OTR) antagonist but not a V1aR antagonist, indicating a possible function of AVP via OTR (24). With regard to reproduction, both OT and AVP induce uterine contractions in nonpregnant mice (Mus musculus) through a mechanism mediated by OTR (25). Overall, these findings indicate possible crosstalk between the OT/IT and AVP/AVT systems.

The OT/OTR system was shown to participate in various physiological processes during the reproductive period (1). OT is important for parturition and acts through its specific receptor (26). OT binding to OTR increases intracellular $\mathrm{Ca}^{2+}$ concentration and thus activates smooth muscle contraction (27). Additionally, OT stimulates prostaglandin (PG) synthesis through a more complex pathway linked to the contraction of the myometrium $(3,27)$. In humans, OT significantly increases prostaglandin $\mathrm{E}_{2}\left(\mathrm{PGE}_{2}\right)$ production by increasing the expression of cyclooxygenase 2 (cox2) mRNA via OTR (28). Treatment of cultured endometrial cells with OT induces COX2 activation and synthesis of $\mathrm{PGF}_{2 \mathrm{a}}$ (29). However, in luteal phase mares, OT downregulated the activities of both COX2 and prostaglandin $\mathrm{E}_{2}$ synthase (PTGES) (30). Thus, OT functions involve regulation of PG synthesis, which may be influenced by the reproductive status.
PGs play a central role in the onset of parturition in mammals and are well-known as inflammatory factors and multifunctional fatty acid derivatives comprising a group of C20 metabolites synthesized from arachidonic acid (AA) through a series of enzyme modifications. The synthesis is initiated by the conversion of AA into the intermediate product $\mathrm{PGH}_{2}$ by COX1 or COX2 followed by synthesis of five bioactive metabolites, including four PGs $\left(\mathrm{PGE}_{2}, \mathrm{PGF}_{2 \mathrm{a}}, \mathrm{PGD}_{2}\right.$, and $\mathrm{PGI}_{2}$ ) and thromboxane (TX) (31-33). PGF $2 \mathrm{a}$ induces the contractions and inflammatory responses in the human myometrium (3). Stimulation of OT release from large luteal cells causes additional $\mathrm{PGF}_{2 \mathrm{a}}$ synthesis and release via a positive feedback mechanism (34). In teleosts, plasma $\mathrm{PGF}_{2 \mathrm{a}}$ levels in successfully ovulated females are significantly higher than those in unsuccessfully ovulated females in small-scale pacu (Piaractus mesopotamicus), indicating the importance of $\mathrm{PGF}_{2 \mathrm{a}}$ in inducing ovulation (35). In goldfish (Carassius auratus), $\mathrm{PGF}_{2 \mathrm{a}}$ functions as a blood-borne behavior hormone that induces spawning behavior $(36,37)$. These experiments suggested that $\mathrm{PGF}_{2 \mathrm{a}}$ has similar activity in inducing ovulation in some externally fertilizing fish.

These studies focused on the effect of IT on teleost spawning behavior mediated by ITR and $\mathrm{PGF}_{2 \mathrm{a}}$. However, unlike other egg-laying teleosts, guppy (Poecilia reticulata) uses ovoviviparous reproductive strategy and gives birth to active larval fish directly. A previous study demonstrated that $\mathrm{PGF}_{2 \mathrm{a}}$, IT and AVT significantly shorten the brood interval of guppies (14); however, the molecular mechanism of this effect remains unclear. The present study investigated the molecular mechanism by which AVT and IT stimulate PGF $_{2 a}$ synthesis via the isotocin receptor (ITR) and subsequently trigger the initiation of parturition in guppies to determine the role of the interaction of AVT and IT with ITR and $\mathrm{PGF}_{2 \mathrm{a}}$ in the regulation in live bearing guppy. The present study is the first to identify and characterize it, avt and itrs in guppies to document the effect of AVT and IT on cox 2 expression and the $\mathrm{PGF}_{2 \mathrm{a}}$ concentration. Finally, the administration of $\mathrm{PGF}_{2 \mathrm{a}}$ to pregnant guppies confirmed the function of AVT-induced $\mathrm{PGF}_{2 \mathrm{a}}$ in parturition in ovoviviparous teleosts.

\section{MATERIALS AND METHODS}

\section{Ethics Statement}

All procedures involved in the handling and treatment of fish in this study were approved by Animal Research and Ethics Committees of Ocean University of China prior to the initiation of the study. All experiments were performed in accordance with relevant guidelines and regulations.

\section{RNA Extraction and Reverse Transcription}

Total RNA was extracted from the guppy brain and ovaries $(n=3)$ using TRIzol ${ }^{\circledR}$ reagent (Invitrogen, Carlsbad, USA) for gene cloning. The quantity and purity of the RNA were estimated using a biophotometer (OSTC, Beijing, China) and agarose gel electrophoresis. One microgram of total RNA was reverse 
transcribed into complementary DNA (cDNA) using a HiScript III RT SuperMix reagent kit (Vazyme, Nanjing, China) according to the manufacturer's instructions.

\section{Gene Cloning and Sequence Analysis of Isotocin, Arg-Vasotocin and Isotocin Receptors in Guppies}

The open reading frames (ORFs) of guppy it, avt, and itrs were obtained from the genome database (PRJNA238429), and the sequences were confirmed by PCR followed by Sanger sequencing. PCR was performed according to the protocol described in a previous report using cDNA samples from the brain or ovary (38). Briefly, initial denaturation was performed at $94^{\circ} \mathrm{C}$ for $3 \mathrm{~min}$ followed by 35 cycles at $94^{\circ} \mathrm{C}$ for $30 \mathrm{~s}, 55^{\circ} \mathrm{C}$ to $60^{\circ} \mathrm{C}$ for $30 \mathrm{~s}$, and $72^{\circ} \mathrm{C}$ for $1 \mathrm{~min}$. The reaction was terminated with an extension for $5 \mathrm{~min}$ at $72^{\circ} \mathrm{C}$. The products were purified using a TIANgel Midi purification kit (TIANGEN, Beijing, China), subcloned into the pEASY-T1 cloning vector (TransGen Biotech, Beijing, China) and transformed into DH5 $\alpha$ cells. Positive clones containing the inserts of the expected size were selected for sequencing to confirm the results. The confirmed sequences were submitted to the NCBI. All primers used in the present study are listed in Table $\mathbf{1}$.

The signal peptide and precursor cleavage sites of IT and AVT were predicted by SignalP 5.0 (39) and NeuroPred software (40), respectively. Seven putative transmembrane domains were predicted by the TMHMM server v. 2.0 (http://www.cbs.dtu.dk/

TABLE 1 | Sequences of the primers used for dual-fluorescence ISH, plasmid construction and qPCR.

\begin{tabular}{|c|c|}
\hline Primers & Sequence $\left(5^{\prime}-3^{\prime}\right)$ \\
\hline \multicolumn{2}{|c|}{ Primers for ORF cloning } \\
\hline itr1-orf-F & ATGGAAACTATITCCAATG \\
\hline itr1-orf-R & TTACGTGGTGGATGTCTGTGT \\
\hline itr2-orf-F & ATGGAGGAAC $\Pi \Pi T A C G C G C A$ \\
\hline itr2-orf-R & TCAGTGCGCGGGCCCCCC \\
\hline avt-orf-F & ATGCATCACTCCCTGCTGTGC \\
\hline avt -orf-R & TCAGTAGTCGTTCTGTCCTCT \\
\hline it-orf-F & TGGCTाCGGCПTCTGGGT \\
\hline it-orf-R & AGAGAGACCTTCGGGTAGCG \\
\hline \multicolumn{2}{|c|}{$\begin{array}{l}\text { Primers for preparation of dual- } \\
\text { fluorescence ISH probes }\end{array}$} \\
\hline itr1-ish-F & CGCAACTTATCTGGGACA \\
\hline itr1-ish-R & $\begin{array}{l}\text { CCGTAATACGACTCACTATAGGGAGAC } \\
\text { ATCACGGTGGTTATCTTCG }\end{array}$ \\
\hline cox2-ish-F & CGCATCCGAGTTCAATAC \\
\hline cox2-ish-R & $\begin{array}{l}\text { CCGATITAGGTGACACTATAGAAGCGT } \\
\text { TCAAACGAGGAGTAGGG }\end{array}$ \\
\hline \multicolumn{2}{|c|}{ Primers for plasmid construction } \\
\hline itr1-orf-PC-F & $\begin{array}{l}\text { ACTATAGGGAGACCCAAGCTTATGGAAA } \\
\text { CTATTCCAATGAAAGTGA }\end{array}$ \\
\hline itr1-orf-PC-R & $\begin{array}{l}\text { TATAGAATAGGGCCCTCTAGATTACGTG } \\
\text { GTGGATGTCTGTGTGA }\end{array}$ \\
\hline \multicolumn{2}{|c|}{ Primers for qPCR } \\
\hline $\cos 2-\mathrm{F}$ & CGCATCCGAGTTCAATAC \\
\hline $\cos 2-\mathrm{R}$ & TTCAAACGAGGAGTAGGG \\
\hline itr1-F & CGCAACTTATCTGGGACA \\
\hline itr1-R & TCACGGTGGTTATCTTCG \\
\hline$\beta$-actin- $\mathrm{F}$ & GCCTATCTACGAGGGCTACGC \\
\hline$\beta$-actin-R & TTGATGTCACGCACGATTCC \\
\hline
\end{tabular}

services/TMHMM-2.0/). Multiple sequences were aligned and analyzed using Clustal X software (41), and phylogenetic trees were constructed using MEGA 6 software (42).

\section{Colocalization of Guppy itr1 and cox2 Using Dual-Fluorescence In Situ Hybridization (ISH)}

Dual-fluorescence in situ hybridization (ISH) for itr1 and cox2 was performed to confirm the regulatory effect of AVT on cox2 via ITR1 using previously described methods with modifications $(43,44)$. Briefly, 10 guppy ovaries at various development stages were collected, fixed with buffered $4 \%$ paraformaldehyde for $24 \mathrm{~h}$ and subsequently embedded in paraffin. Next, 7-mm thick sections were cut for ISH. For double ISH, the probes for itr1 and cox 2 were labeled with digoxigenin (DIG) and biotin (Roche Diagnostics, Mannheim, Germany), respectively. After hybridization with a mixture of both probes and posthybridization steps, the sections were washed and blocked with blocking buffer (10\% goat serum, Invitrogen, Carlsbad, USA). The sections were incubated with a horseradish peroxidase (HRP)-conjugated anti-DIG secondary antibody (diluted 1:500 with blocking buffer, Roche Diagnostics, Mannheim, Germany) and rinsed twice with sterile phosphate-buffered saline (PBS) for 5 min each time; then, chromogenic reactions were performed using a tyramide kit with Alexa Fluor 488 (Invitrogen) for $30 \mathrm{~min}$. The second fluorescence detection started only when the first reaction appeared to produce appropriate results. The sections were incubated with $3 \%$ hydrogen peroxide for $1 \mathrm{~h}$ to inactivate HRP conjugated to anti-DIG antibody. After several rinsing steps, the sections were incubated with HRP-conjugated streptavidin (Proteintech, Chicago, USA). The final chromogenic reaction was performed using a tyramide kit with Alexa Fluor 594 (Invitrogen) for $30 \mathrm{~min}$ and stopped by adding working solution of stop reagent (Invitrogen, Carlsbad, USA) to detect the signal. The sections were mounted in antifade mounting medium (Beyotime, Shanghai, China) after nuclear staining with DAPI for $10 \mathrm{~s}(10 \mu \mathrm{g} / \mathrm{mL}$, Solarbio, Beijing, China). Images were captured using an Olympus BX53F fluorescence microscope (Olympus, Japan).

\section{In Vitro Ovary Incubation Assays}

The guppy nonapeptides AVT and IT were synthesized by GL Biochem (Shanghai, China). The purity of the synthesized peptides was determined to be $>95 \%$ using analytical HPLC. The nonapeptides were dissolved in dimethyl sulfoxide (DMSO, Solarbio, Beijing, China). Tissue culture was performed mainly using an established protocol (45). Briefly, whole ovaries from five fertilized female guppies $(1.15 \pm 0.09 \mathrm{~g})$ per group were collected and washed three times with PBS containing $100 \mathrm{U} / \mathrm{mL}$ penicillin, $1 \mathrm{mg} / \mathrm{mL}$ streptomycin and $1.25 \mathrm{U} / \mathrm{mL}$ nystatin. After preincubation with Leibovitz's L-15 medium in a 12-well plate at $28^{\circ} \mathrm{C}$ for $2 \mathrm{~h}$, the ovarian fragments were incubated in fresh medium containing various doses of AVT or IT $\left(10^{-5}, 10^{-6}\right.$, or $10^{-7} \mathrm{~mol} / \mathrm{L}$ ) for $3 \mathrm{~h}$ or with $10^{-5} \mathrm{~mol} / \mathrm{L} \mathrm{AVT}$ or IT for various times $(3,6$, or $9 \mathrm{~h})$. The fragments incubated with DMSO were used as the controls. At the end of the incubation, the fragments 
were collected and stored at $-80^{\circ} \mathrm{C}$ for RNA extraction and qPCR analysis.

\section{Quantitative Real-Time PCR}

The expression of itr1 and cox2 in guppies was analyzed by quantitative real-time PCR (qPCR) with specific primers. The samples were generated from ovary fragments incubated with various concentrations of the stimulatory agents at various time points as indicated. All cDNA products obtained by RNA extraction and reverse transcription were diluted to $500 \mathrm{ng} / \mu \mathrm{l}$. The $20-\mu \mathrm{L}$ qPCR reaction mixture contained $2 \mu \mathrm{L}$ of cDNA templates, $0.4 \mu \mathrm{L}$ of both primers, $10 \mu \mathrm{L}$ of KAPA SYBR ${ }^{\circledR} \mathrm{FAST}$ qPCR Master Mix (2X), $0.4 \mu \mathrm{L}$ of 6-carboxy-X-rhodamine (ROX) and $6.8 \mu \mathrm{L}$ of RNase-free water. PCR amplification was performed in a 96 -well optical plate at $95^{\circ} \mathrm{C}$ for $30 \mathrm{~s}$ followed by 40 cycles at $95^{\circ} \mathrm{C}$ for $5 \mathrm{~s}$ and $58^{\circ} \mathrm{C}$ for $30 \mathrm{~s}$, and a final extension was performed at $72^{\circ} \mathrm{C}$ for $2 \mathrm{~min}$. qPCR was performed using a StepOne Plus real-time PCR system (Applied Biosystems), and the $2^{-\Delta \Delta C T}$ method was used to calculate the gene expression levels.

\section{Plasmid Construction and Luciferase Assay}

The human embryonic kidney 293T (HEK-293T) cell line was used for the binding activity assays. The ORF of the guppy itr1 cDNA was subcloned into the pcDNA3.1a expression vector (Invitrogen, Carlsbad, USA). Prior to the transfection, 293T cells were maintained at $37^{\circ} \mathrm{C}$ in DMEM containing $10 \%$ fetal bovine serum (FBS) (Thermo Fisher Scientific, Massachusetts, USA). Twenty hours before the transfection, $1 \times 10^{5}$ cells were seeded into the wells of 24-well tissue culture plates. Then, $500 \mathrm{ng}$ of pCRE-Luc reporter plasmid, $300 \mathrm{ng}$ of pcDNA3.1-itr1 and $50 \mathrm{ng}$ of pRL-CMV (to normalize transfection efficiency) containing the Renilla luciferase sequence were transiently cotransfected into the cells in $500 \mu \mathrm{L}$ of serum-free medium using Lipofectamine reagent (Invitrogen, Carlsbad, USA). Six hours after the transfection, the cells were incubated in DMEM (10\% FBS) for $12 \mathrm{~h}$ and subsequently treated with the vehicle or various concentrations of IT and AVT $\left(10^{-6}, 10^{-7}\right.$, or $10^{-8}$ $\mathrm{mol} / \mathrm{L}$ ) for an additional $6 \mathrm{~h}$. Each treatment was replicated in four wells. Then, the cells were harvested, and luciferase activity assays were performed using a dual-luciferase kit (Promega, Wisconsin, USA).

\section{ELISA Measurement of the PGF $_{2 a}$ Concentration}

To assess the $\mathrm{PGF}_{2 \mathrm{a}}$ concentrations after IT and AVT injections, 24 pregnant guppies were intraperitoneally injected with IT $(1 \mu \mathrm{g} / \mathrm{g})$, AVT $(1 \mu \mathrm{g} / \mathrm{g})$ or the same volume of saline solution. Tissue homogenates from each individual were collected $3 \mathrm{~h}$ after the injection. The homogenate was obtained by centrifugation of the samples at $12,000 \mathrm{~g}$ for $10 \mathrm{~min}$ after an overnight incubation at $4^{\circ} \mathrm{C}$, and the $\mathrm{PGF}_{2 \mathrm{a}}$ level was measured in duplicate samples using commercial ELISA kits (Runyu, Shanghai, China) according to the manufacturer's instructions.

\section{$\mathrm{PGF}_{2 \mathrm{a}}$ Injection and Parturition Behavioral Assay}

Parturition behavioral assays were conducted in 2-L rectangular tanks. Guppies were selected and treated 20 days after the last delivery, and 10 individuals were housed in two 5 - $\mathrm{L}$ water tanks with water temperature of $28^{\circ} \mathrm{C}$ before the injection. One pregnant individual from each tank was acclimated for 2 days to standardize the effect of environmental changes. $\mathrm{PGF}_{2 \mathrm{a}}$ (Shanghai Yuanye Bio-Technology, China) was injected at a concentration of $1,000 \mathrm{ng} / \mathrm{g}$ body wet weight to verify whether $\mathrm{PGF}_{2 \mathrm{a}}$ has a direct effect on parturition. $\mathrm{PGF}_{2 \mathrm{a}}$ was dissolved in ethanol at a concentration of $100 \mu \mathrm{g} / \mathrm{mL}$, as described in a previous study of PG administration in guppy (14), with several modifications. Individuals in the control group were injected with an equal volume of ethanol. All reactions were recorded with a digital video camera. The treatment and control were administered at the same time. The experiment was replicated three times. The offspring were collected and imaged using a microscope (Optec, China) to analyze the morphology.

\section{Statistical Analysis}

All data are presented as the mean values \pm S.E.M. The $P F_{2 a}$ concentration and gene expression in response to various concentrations of the hormones and at various treatment times were analyzed using one-way ANOVA followed by Duncan's and Dunnett's T3 multiple range tests. Gene expression in guppy treated with various hormones at the same time points were analyzed using independent sample $\mathrm{T}$ test. $\mathrm{P}$-values $<0.05$ were considered to be significant. All statistical analyses were performed using SPSS 19.0 software (SPSS, Chicago, IL, USA).

\section{RESULTS}

\section{Gene Cloning and Sequence Analysis of AVT, IT, and ITRs in Guppies}

Genomic data mining and gene cloning showed that the open reading frame (ORF) of avt (MW050982) is 456 bp and encodes a 151-amino acid (aa) precursor with a predicted signal peptide of 16 aa (Figure 1A). The precursor cleavage site analysis showed that the putative nonapeptide is located from aa 18 to aa 27 (Figure 1A). Comparison of the deduced amino acid sequences revealed that teleost AVT nonapeptides are highly conserved with avian AVTs and human AVP, except for a mutation site at position 3 (Gln/Ser) (Figure 1B). A phylogenetic tree of AVP precursors was constructed, and AVTs from teleosts and avians were clustered into a single clade, along with mammalian AVPs (Figure 1C).

Genomic data mining and gene cloning indicated that the ORF (MW050983) of it is $468 \mathrm{bp}$ and encodes a 155 aa precursor with a predicted signal peptide of 18 aa (Figure 2A). The putative nonapeptide extends from 20 aa to 28 aa based on precursor cleavage site analysis (Figure 2A). Comparison of the deduced amino acid sequences indicated that the IT nonapeptides are highly conserved among teleosts and similar to human OT and chicken mesotocin (MT), except for two mutation sites at 


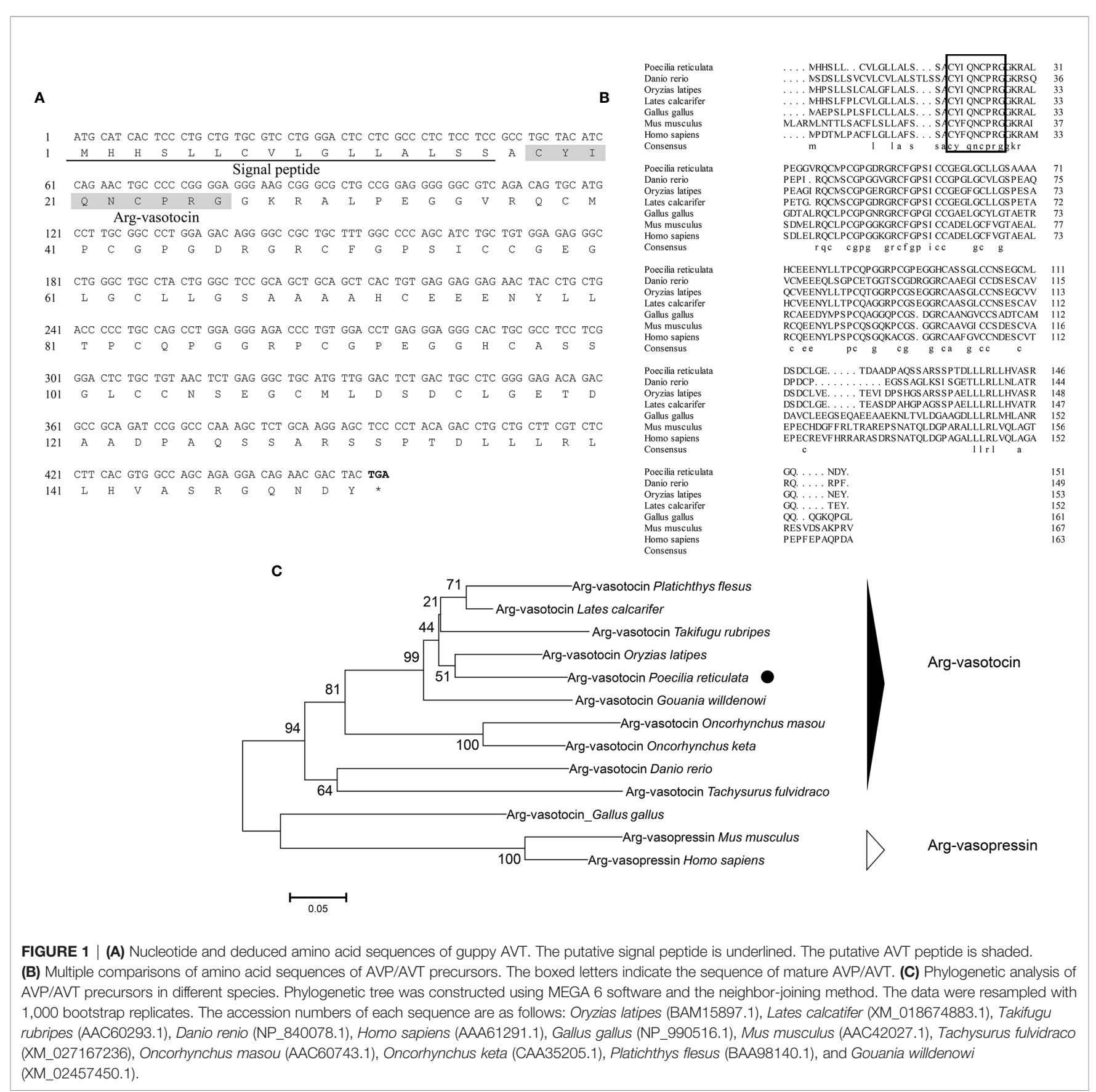

positions $4(\mathrm{Gln} / \mathrm{Ser})$ and 8 (Leu/Ile) (Figure 2B). A phylogenetic tree of OT-like precursors revealed the clustering of teleost ITs into a single clade with mammalian OTs and avian and tetrapod MTs (Figure 2C). As neuropeptides with nine amino acids, both AVT and IT show high sequence conservation, except for Gln/ Ser at position 4 and Arg/Ile at position 8. Both peptides contain disulfide bonds between cysteine (Cys) residues at positions 1 and 6 (Figure 3).

Genomic data revealed 2 oxytocin-like receptor genes in guppies. The size of the oxytocin receptor gene is $1,173 \mathrm{bp}$, and the gene encodes a 390-aa G protein-coupled receptor; the classical 7-transmembrane domain structure is annotated in Figure 4A.
The ORF of itr is 1,188 bp, coding for a 395-aa G protein-coupled receptor with seven transmembrane domains (Figure 4B).

Teleosts clustered together in the phylogenetic tree of both OTlike receptors. Teleosts, including zebrafish, guppy, medaka (Oryzias latipes), large yellow croaker (Larimichthys crocea), and gilt-head bream (Sparus aurata), express two types of the receptors, which were previously known as OTRs and ITRs. In the present study on guppies, the oxytocin receptor was renamed isotocin receptor 1 (ITR1, MN725111), and the isotocin receptor was renamed isotocin receptor 2 (ITR2, MW050984). However, oxytocin-like receptors in non-teleosts display greater evolutionary distance, suggesting that they are relatively conserved in teleosts (Figure 4C). 
A

1 ATg TCT GGA GCT GCC GTG TCC GTG GGC CTG CTT TTC CTC CTG TCC GTT TGT TCG GCG TGT

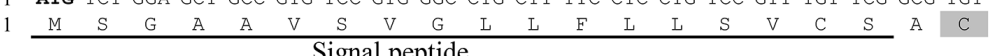
Signal peptide

61 TAC ATC TCC AAC TGC CCC ATC GGT GGA AAg AGG TCA ATC ATG GAT GCT CCT CTC CGA AAg \begin{tabular}{l|llllllllllllllllllll}
21 & $\mathrm{Y}$ & $\mathrm{I}$ & $\mathrm{S}$ & $\mathrm{N}$ & $\mathrm{C}$ & $\mathrm{P}$ & $\mathrm{I}$ & $\mathrm{G}$ & $\mathrm{G}$ & $\mathrm{K}$ & $\mathrm{R}$ & $\mathrm{S}$ & $\mathrm{I}$ & $\mathrm{M}$ & $\mathrm{D}$ & $\mathrm{A}$ & $\mathrm{P}$ & $\mathrm{I}$ & $\mathrm{R}$ & $\mathrm{K}$
\end{tabular} isotocin

121 TGC ATG TCT TGT GGC CCT GGA GAC CGG GGC CGC TGC TAC GGC CCC AGC ATC TGC TGT GGG $\begin{array}{llllllllllllllllllllllll}41 & C & M & S & C & G & P & G & D & R & G & R & C & Y & G & P & S & I & C & C & G\end{array}$

181 GAG GGC ATC GGC TGC CTC TTG GGC TCC CCT GAG TCG GCA CAC TGC GTG GAG GAG AAC TAC $\begin{array}{lllllllllllllllllllll}61 & \mathrm{E} & \mathrm{G} & \mathrm{I} & \mathrm{G} & \mathrm{C} & \mathrm{L} & \mathrm{L} & \mathrm{G} & \mathrm{S} & \mathrm{P} & \mathrm{E} & \mathrm{S} & \mathrm{A} & \mathrm{H} & \mathrm{C} & \mathrm{V} & \mathrm{E} & \mathrm{E} & \mathrm{N} & \mathrm{Y}\end{array}$

241 Ctg CTC ACC CCC TGT CAg GCC Ggt GgG AGA GCC TGT GGC TCA GAg GgA GGA CGC TGC GCC $\begin{array}{lllllllllllllllllllllll}81 & \mathrm{~L} & \mathrm{~L} & \mathrm{~T} & \mathrm{P} & \mathrm{C} & \mathrm{Q} & \mathrm{A} & \mathrm{G} & \mathrm{G} & \mathrm{R} & \mathrm{A} & \mathrm{C} & \mathrm{G} & \mathrm{S} & \mathrm{E} & \mathrm{G} & \mathrm{G} & \mathrm{R} & \mathrm{C} & \mathrm{A}\end{array}$ 301 GCT GCA GGA CTT TGC TGC GAT GCA GAA AGC TGC ACT GCA GAT CAG TCG TGC CTC CCT GAG $\begin{array}{lllllllllllllllllllll}101 & \text { A } & \text { A } & G & \text { L } & \text { C } & C & \text { D } & \text { A } & \text { E } & \text { S } & \text { C } & \text { T } & \text { A } & \text { D } & \text { \& } & \text { S } & \text { C } & \text { I } & \text { P } & \text { E }\end{array}$ 361 GAC GAC GGA GAC GAC CAA AGC AGC CAG TTG GAA GGC GGT GAC CCC ACC GAC ATC ATC CTC $\begin{array}{llllllllllllllllllllllll}121 & D & D & G & D & D & Q & S & S & Q & L & E & G & G & D & P & T & D & I & I & L\end{array}$

421 AGg CTC CTG CAT CTG GCC CGC CAC ACT TCT CAC CGA ACC CAC CAA TGA

$\begin{array}{lllllllllllllllll}141 & R & L & L & H & L & A & R & H & T & S & H & R & T & H & Q & *\end{array}$

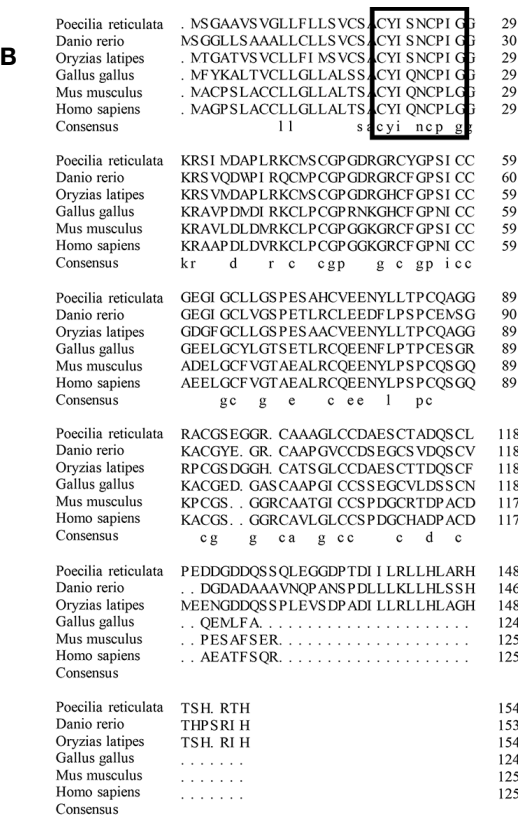

29
30
29
29
29
29

59
60
59
59
59
59

89
90
89
89
89
89

118
118
118
118
117
117

148
146
148
124
125
125

154
153
154
124
125
125
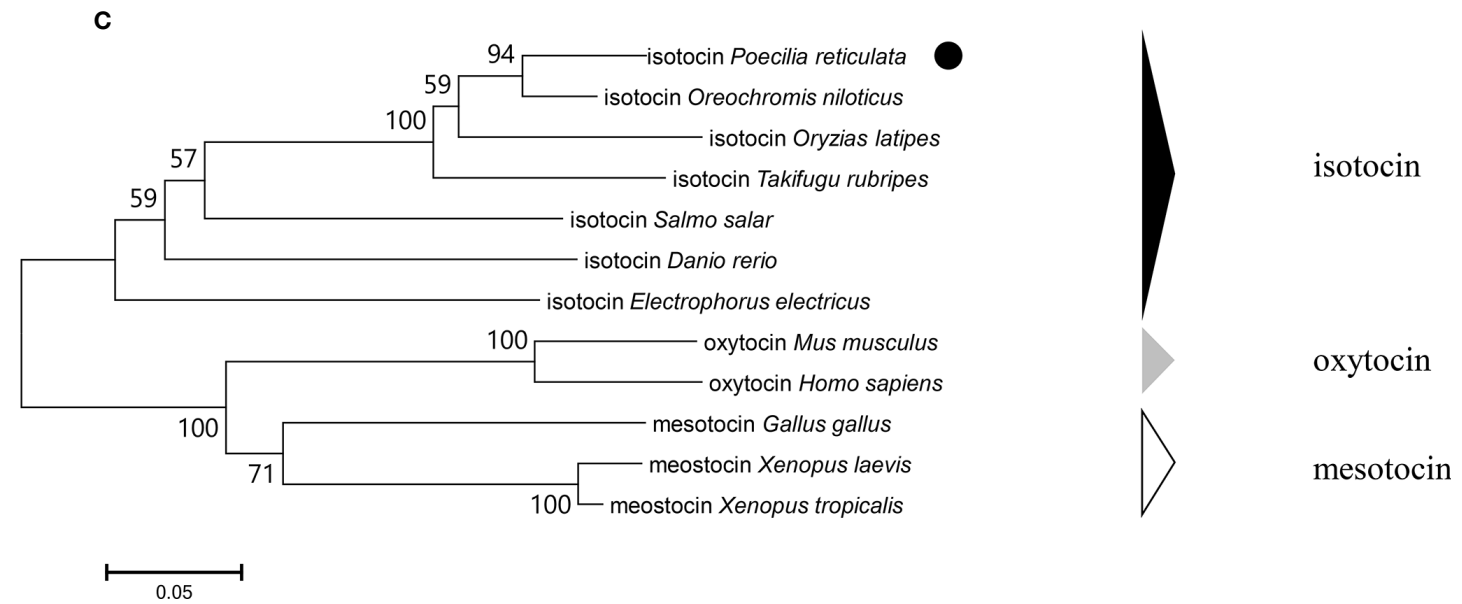

FIGURE 2 | (A) Nucleotide and deduced amino acid sequences of guppy IT. The putative signal peptide is underlined. The putative IT peptide is shaded. (B) Multiple comparisons of the amino acid sequences of OT/IT/MT precursors. The boxed letters indicate the sequence of mature OT/IT/MT. (C) Phylogenetic analysis of IT precursors in different species. The phylogenetic tree was constructed using MEGA 6 software and the neighbor-joining method. The data were resampled with 1,000 bootstrap replicates. The accession numbers of each sequence are as follows: Oryzias latipes (NP_001265759.1), Salmo salar (ABU80634.1), Takifugu rubripes (AAC60289.1), Danio renio (AAL50209.1), Homo sapiens (NP_000906.1), Gallus gallus (QCX08109.1), Mus musculus (NP_035155.1), Electrophorus electricus (XP_026855497.1), Oreochromis niloticus (XP_003446141.1), Xenopus laevis (XP_018080922.1), and Xenopus tropicalis (XP_002936405.1).

\section{cAMP Response Element-Luciferase- Based Characterization of the Effects of AVT on Guppy ITR}

A binding assay was performed using the cAMP response element (CRE)-luciferase reporter assay system to determine whether guppy IT and AVT bind ITR1 and regulate the downstream gene expression. The ORF of itr1 (pcDNA3.1a), pGL3 (CRE-luciferase), and pRL-TK were cotransfected into HEK293T cells, which were incubated with various concentrations of IT and AVT for $24 \mathrm{~h}$. Both IT and AVT at the concentrations of $10^{-6}, 10^{-7}$, and $10^{-8} \mathrm{~mol} / \mathrm{L}$ significantly activated ITR1 $(\mathrm{P}<0.05)$ (Figures 5A, B). The CRE-luciferase reporter assays demonstrated a dose-dependent response to the IT injection, and the luciferase activity corresponding to ITR1 induction by AVT was not dose-dependent.

\section{Effects of IT and AVT on the Levels of cox2 and itr1 mRNAs in the Guppy Ovaries}

In vitro incubation of ovarian fragments was performed to evaluate the effects of IT and AVT on the expression of cox2 and itr1 mRNAs. The sequences of cox2 (XM_008415162.2) and $\beta$-actin (EU143772.1) were identified using the NCBI database. 


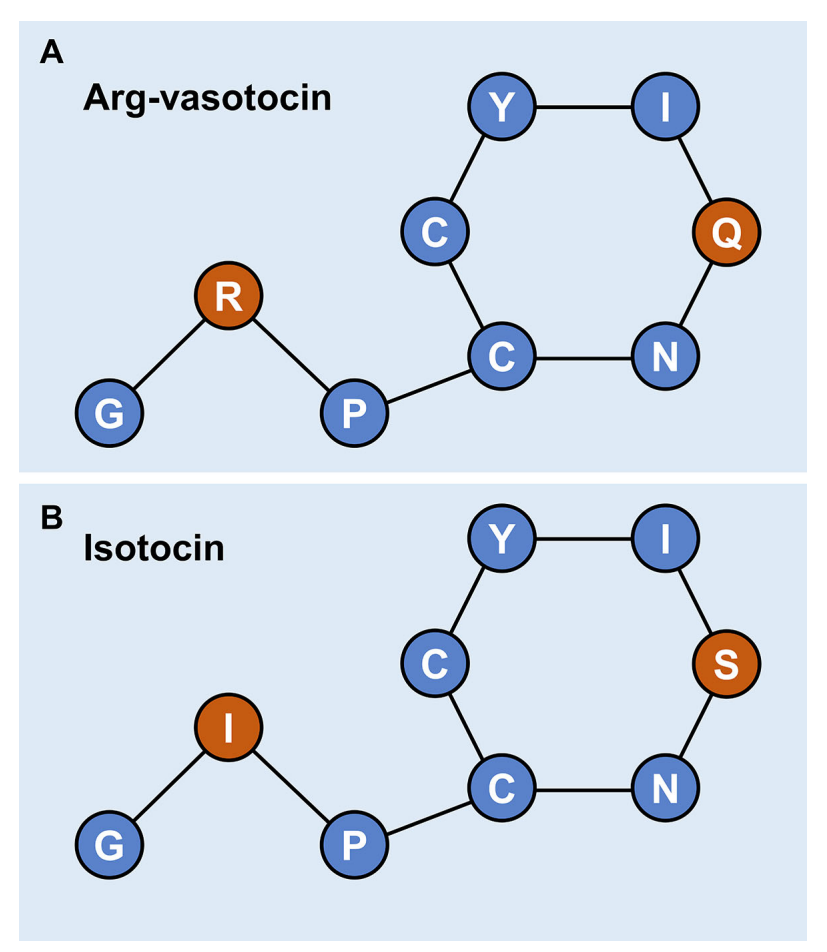

FIGURE 3 | Schematic diagrams of the primary structures of guppy AVT (A) and IT (B). Different amino acids at positions 4 and 8 are highlighted in red.

qPCR was performed to measure the expression of $\operatorname{cox} 2$ and itr1. $\beta$ Actin was used as an internal control. The expression of cox 2 was significantly upregulated $(\mathrm{P}<0.05)$ in the presence of high concentrations of AVT $\left(10^{-5} \mathrm{~mol} / \mathrm{L}\right)$ compared with that in the control group and in the samples treated with IT (Figure 6A). The expression of itr 1 was also significantly increased $(\mathrm{P}<0.05)$ by all concentrations of AVT compared with that in the samples treated with IT (Figure 6B). The results of time-dependent treatment experiments indicated that the expression levels of cox 2 and itr 1 were significantly induced $(\mathrm{P}<0.05)$ at $3 \mathrm{~h}$ and rapidly decreased $(\mathrm{P}<0.05)$ at $6 \mathrm{~h}$ before returning to the normal levels at $9 \mathrm{~h}$ in the presence of a high concentration of AVT $\left(10^{-5} \mathrm{~mol} / \mathrm{L}\right)$ (Figures 7A, B). In contrast to AVT stimulation, the expression levels of cox 2 and itrl were significantly induced $(\mathrm{P}<0.05)$ at $6 \mathrm{~h}$ and rapidly decreased $(\mathrm{P}<0.05)$ at $9 \mathrm{~h}$, returning to the normal levels at $9 \mathrm{~h}$ in the presence of a high concentration of IT $\left(10^{-5} \mathrm{~mol} / \mathrm{L}\right)$ (Figures 7C, D).

\section{Colocalization of itr1 and cox2 in the Ovaries of Female Guppies}

Dual-fluorescence ISH of itr 1 and cox 2 was performed in the ovary at two different developmental stages to determine possible direct regulatory effect of AVT on cox 2 expression mediated by ITR1. As shown in Figure 8, itr1-and cox2-positive signals were present in the inner follicular cell layer of late vitellogenesis-stage oocytes, indicating that the individual was fertilizable and ready for parturition and that ITR1 may regulate the expression of cox 2 (Figure 8H). However, positive signal of itr 1 was not detected in early vitellogenesis-stage oocytes (Figure 8D), suggesting that itr1 expression was significantly influenced by oocyte development stage. On the other hand, positive signals of itr 1 were observed in ovarian stromal cells. Follicles at both stages are indicated with white arrowheads (late vitellogenesis stage oocyte follicles) and open arrowheads (early vitellogenesis stage oocyte follicles) in Figure $\mathbf{8 H}$, showing that itr1 is only expressed in the follicular layer of late vitellogenesis-stage oocytes.

\section{Analysis of $\mathrm{PGF}_{2 \mathrm{a}}$ Concentrations in IT-and AVT-Treated Guppies}

$\mathrm{PGF}_{2 \mathrm{a}}$ concentrations were measured to test the effect of neuropeptides on $\mathrm{PGF}_{2 \mathrm{a}}$ biosynthesis in guppy. AVT induced $\mathrm{PGF}_{2 \mathrm{a}}$ synthesis $(\mathrm{P}<0.05)$ compared with that in the control group and IT group $3 \mathrm{~h}$ after intraperitoneal (IP) injection. The values in the IT and control groups were not significantly different from each other (Figure 9).

\section{Administration of $\mathrm{PGF}_{2 \mathrm{a}}$ to Pregnant Guppies Induced Premature Parturition}

An IP injection of $\mathrm{PGF}_{2 \mathrm{a}}(1,000 \mathrm{ng} / \mathrm{g}$ body wet weight) into pregnant guppies induced parturition behavior in immature larval fish. Supplementary Video 1 shows that the first delivery occurred approximately $1 \mathrm{~h}$ after the IP injection (9:43 AM local time), and no clear variations in parturition behavior were observed in the control, IT-injected (500 ng/g) and AVTinjected groups $(500 \mathrm{ng} / \mathrm{g}$ ) (data not shown). Up to three dead larval fish at most were observed after $\mathrm{PGF}_{2 \mathrm{a}}$ injection in a guppy. Eleven dead larval fish were observed.

$\mathrm{PGF}_{2 \mathrm{a}}$ administration significantly induced the premature parturition of guppies. As shown in Figure 10, premature larval fishes retained a larger yolk sac and lower melanin distribution on the body compared with those in the control group (ethanol). The bodies of the larval fish in the control group showed considerably more stretching than those in the $\mathrm{PGF}_{2 \mathrm{a}}{ }^{-}$ injected group due to the lack of skeletal muscle development under premature conditions.

\section{DISCUSSION}

Nonapeptide hormones have been identified in the endocrine system in various vertebrates. AVP and its homolog AVT are highly conserved, except position 3, which contains Phe in AVP and Ile in AVT. These peptides are named based on the presence of Arg at position 8. Comparison of OT and IT indicated that OT contains Gln at position 4 and Leu at position 8 , and these amino acids are replaced with Ser and Ile, respectively, in IT. In teleosts, which are the predecessors of land vertebrates, amino acid sequences of the AVT and IT nonapeptides share homology, except positions 4 and 8 (1). Thus, two evolutionary lineages have been proposed, the IT-OT line and AVT-AVP line, and both lineages are associated with reproductive functions and behaviors $(1,22)$. High conservation between IT and AVT was confirmed in the present study by gene cloning and sequence analysis of an IT precursor, an AVT precursor and two ITRs of 
A

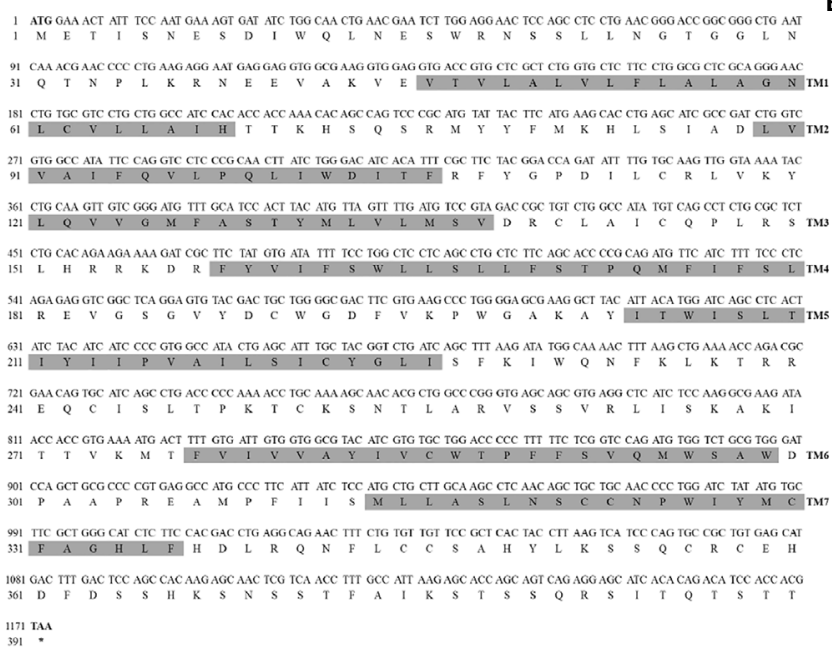

1 ATG GAG GAA CIT TIA CGCGCA CAG GAT GCT TGG GCT CAG AAC GTT TCC TGG TAC AAC TCC AGT CAT ATA AACAGC ACC AAT GTA GGGAAC

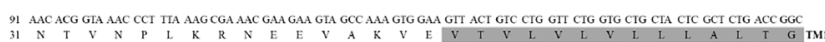

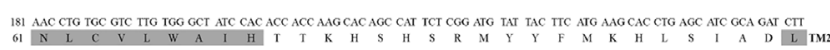
271 GTC GTG GCG GTG TTC CAG GTC CTG CCG CAG CTC ATC TGG GAC ATA ACG ITC CGC TIT TAC GGA CCC GAT TIC CIT TGC AGG CTG GTC AA M

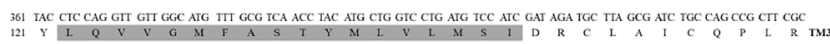

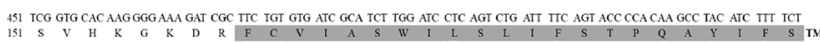
54 CTC AGG GAG GTC GGG AMT GGC GTT IAC GAC IGC TGG GGGGAC TIC GTG GAACCC TGG GGT GCC AAA GCC TAC ATC ACA TGG ATG AGT CTG 631 AGC ATT TAC ATT CIT CCA GTA GCG ATA TIA AGC ATC TGC TAC GGC CTG ATA TGC TTT AAA ATA TGG CAG AAT ATC AAC ATG AaAACCCAGG 721 AGGGAG CAC TIT TTG GCT CTC ACG CCG AGG CCA TCC AAGGGC GCA CAT CCA CTG TCA CGC GIG AGC AGC GTC AGA CTC AIT TCT AAAGC

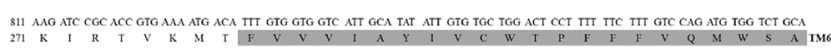

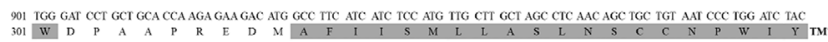

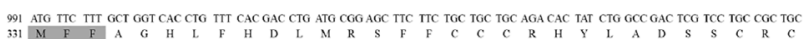

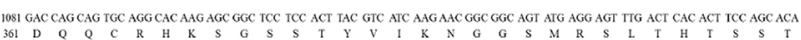

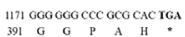
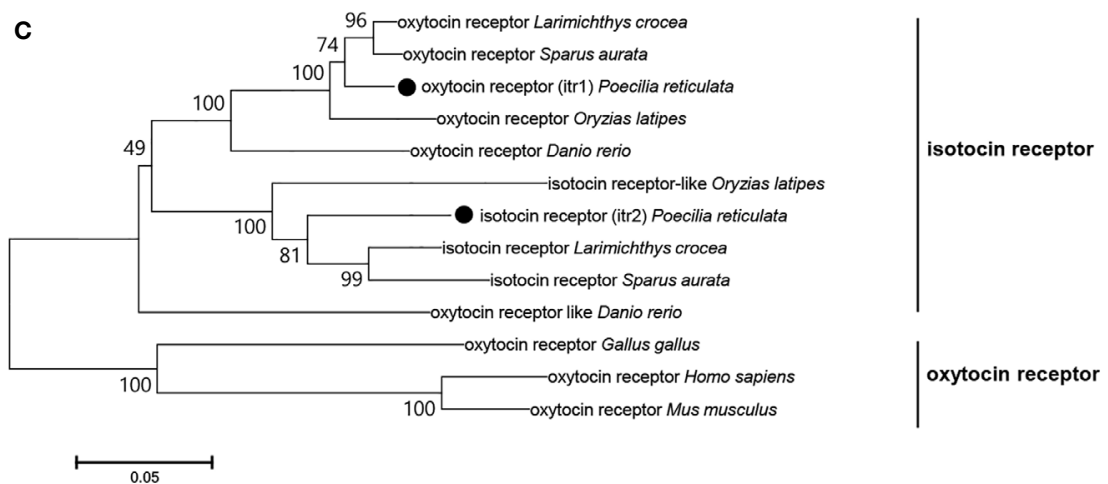

FIGURE 4 | Nucleotide and deduced amino acid sequences of guppy ITR1 (A) and ITR2 (B). The shading represents transmembrane domains. (C) Phylogenetic analysis of the OTR family in different species. Phylogenetic tree was constructed using MEGA 6 software and the neighbor-joining method. The data were resampled with 1,000 bootstrap replicates. The accession numbers of each sequence are as follows: Carassius auratus (XP_026116839.1), Salvelinus alpinus (XP_023846756.1), Mastacembelus armatus (XP_026163763.1), ITR1 Oncorhynchus mykiss (XP_021466000.1), ITR2 Oncorhynchus mykiss (XP_021465666.1), ITR1 Seriola lalandi dorsalis (XP_023257499.1), ITR2 Seriola lalandi dorsalis (XP_023265951.1), Cynoglossus semilaevis (XP_016892293.1), ITR1 Danio rerio (NP_001186298.1), ITR2 Danio rerio (NP_001186299.1), Gallus gallus (NP_001026740.1), Homo sapiens (NP_000907.2), Mus musculus (NP_001074616.1), Oryzias latipes (NP_001243561.1), Paramormyrops kingsleyae (XP_023661236.1), Perca flavescens (XP_028431436.1), Stegastes partitus (NP_001281113.1), Poecilia formosa (XP_007570475.1), and Paralichthys olivaceus (XP_019942082.1).

guppy. The predicted conserved disulfide bridge was formed by Cys residues 1 and 6. Nonapeptides were classified into AVTand OT-like families according to the 8 th amino acid, which is essential for activating the corresponding receptors $(1,46)$. Basic amino acids, such as Arg, are present at this position in AVT, and neutral amino acids are present in OT-like peptides $(1,46)$.

In teleosts, the production of IT is primarily observed in the preoptic area (POA); however, ITRs are distributed in various tissues (47). The present study in guppies identified and cloned two itrs in agreement with reports in other teleosts, including zebrafish (48), medaka (49) and bicolor damselfish (Stegastes partitus) (50). These patterns originated due to two rounds of whole-genome duplication events in vertebrates (2R), which produced one otr and five avp receptors, and the third round in teleosts (3R) subsequently produced two local duplicates of $i t r s$ (51). In mammals, one OT receptor (OTR) and three AVP receptors (V1aR, V1bR, and V2R) have been identified in various peripheral tissues $(52,53)$. Regardless of the similarity of these receptors (25\%), the selectivity of OT and AVP for these receptors varies between species and tissues $(22,54)$. Notably, AVP has similar affinity for OTR, V1aR, and V1bR $(22,55,56)$. The OT receptor has the same affinity to hormones with cyclic structures and Arg-8 (AVT) or Leu-8 (OT) (1).

In vertebrates, OT has been shown to stimulate $\mathrm{PG}$ synthesis by upregulating $\operatorname{cox} 2$ gene expression to induce the conversion of AA to a PG precursor $(3,27,28)$. Further studies showed that in cultured endometrial explants, cox 2 mRNA expression and $\mathrm{PGF}_{2 \mathrm{a}}$ synthesis were increased by OT stimulation and were abolished by the OT antagonist atosiban (29). Similarly, in pre-labor human amnion epithelial cells, incubation with OT resulted in a significant increase in $\mathrm{PGE}_{2}$ levels mediated by upregulation of cox 2 expression (28). In addition, the synthesis of PGs was observed in the follicles of human 

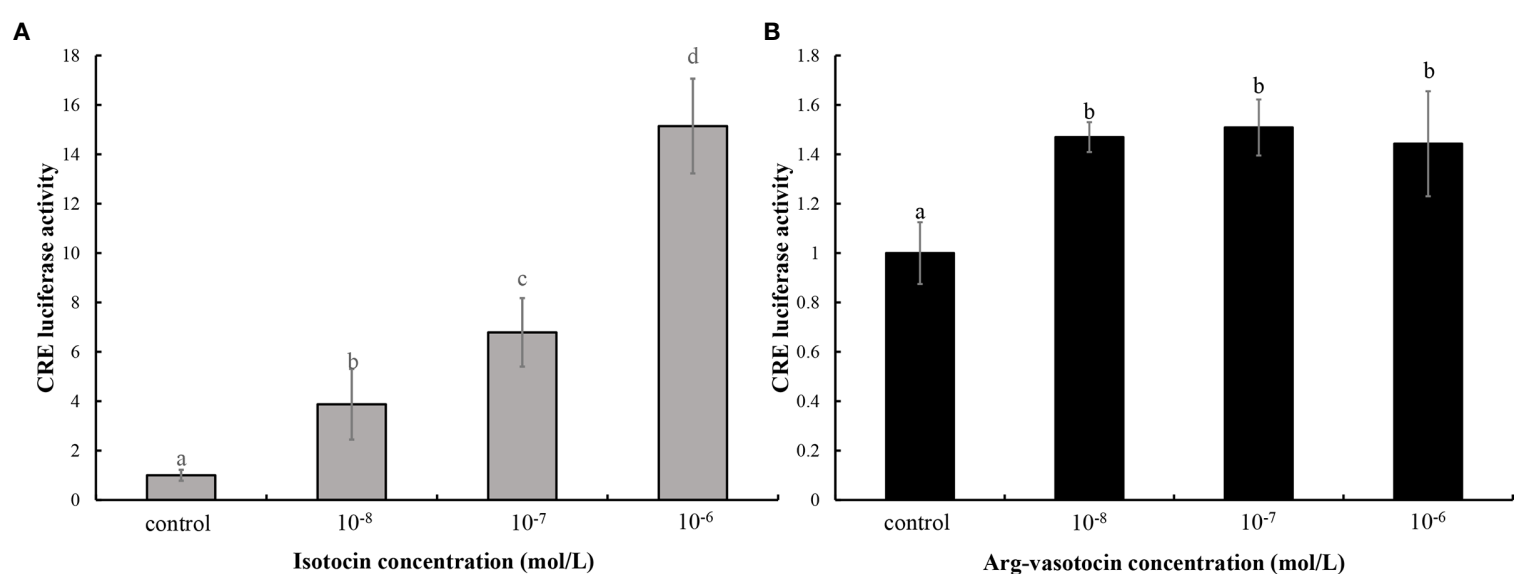

FIGURE 5 | The assay of IT (A) and AVT (B) binding to ITR1. The relative CRE luciferase activity in the presence of various concentrations of IT (10-6, $10^{-7}$, or $10^{-8}$ $\mathrm{mol} / \mathrm{L})$ and $\mathrm{AVT}\left(10^{-6}, 10^{-7}\right.$, or $\left.10^{-8} \mathrm{mo} / \mathrm{L}\right)$ was determined by measuring firefly and Renilla luciferase activities normalized to the values in the control group. Bars represent the mean values \pm SEM, and different letters indicate significant differences $(P<0.05)$.
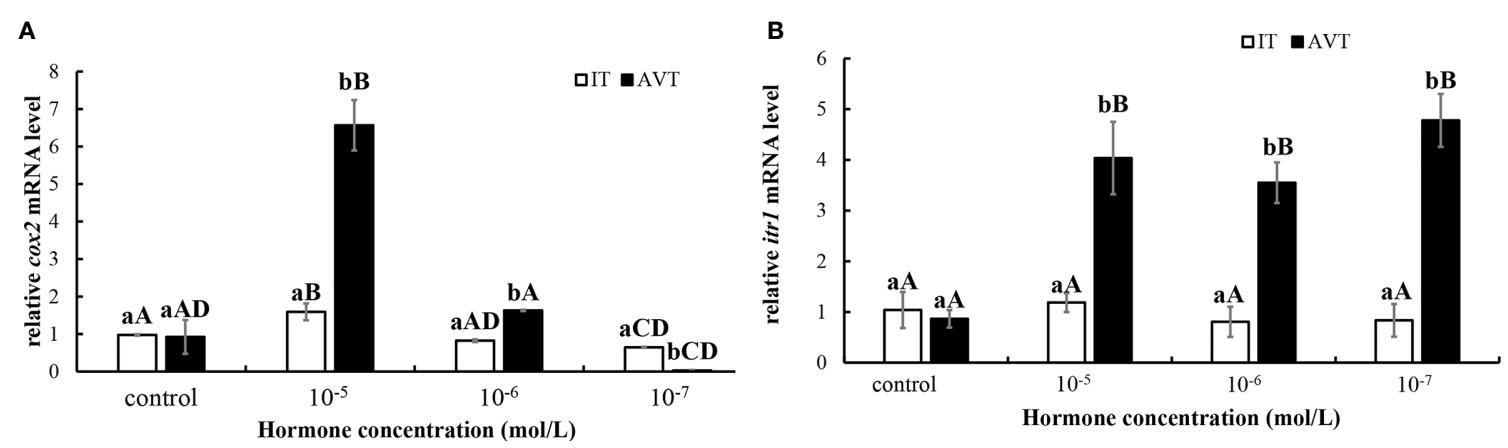

FIGURE 6 | Dose-dependent effects of AVT and IT on the expression of cox2 and itr1 mRNAs in guppy ovary fragments. Ovary fragments were incubated with AVT or IT at the concentrations of $10^{-5} \mathrm{~mol} / \mathrm{L}, 10^{-6} \mathrm{~mol} / \mathrm{L}$ or $10^{-7} \mathrm{~mol} / \mathrm{L}$ for $3 \mathrm{~h}$, and the levels of cox2 (A) and itr1 (B) mRNAs were measured using $\mathrm{qPCR}(\mathrm{n}=5)$. The results are presented as the mean \pm SEM and as fold changes in the expression levels versus the corresponding controls. Different capital letters indicate significant differences between the groups treated with each concentration of a hormone $(P<0.05)$. Different lowercase letters indicate significant differences between the two hormone treatments at the same concentration $(P<0.05)$.

ovaries (57). These studies demonstrated that OT upregulates the cox2 gene by signaling via OTR. Similarly, the studies in teleosts were focused on the role of PGs in the reproductive process, including follicle rupture, ovulation, and spawning (58-60). Notably, a study on catfish (Heteropneustes fossilis) demonstrated that AVT is the main factor stimulating $\mathrm{PGF}_{2 \mathrm{a}}$ synthesis (61). However, it is not known whether AVT stimulates $\mathrm{PGF}_{2 \mathrm{a}}$ secretion via OTR similar to OT/IT. The results of the present study indicated that itr 1 and $\operatorname{cox} 2$ are colocalized in the inner follicular cell layer that produces PGs. Furthermore, merged itr1/cox2 signals were also observed in ovarian stromal cells, where PGs were reported to play a role in the immune reaction (31).

The CRE-luciferase assay was performed to evaluate the affinity of AVT and IT for ITR1 and to confirm our hypothesis that AVT regulates cox 2 mRNA expression via ITR1. The results showed that both IT and AVT bind to ITR1; however, AVT does not display dose-dependent effects. These data are supported by previous studies showing that AVT activates teleost ITRs with lower potency than that of IT (62). AVT has a similar affinity for OTR, V1aR and V1bR (22). Then, we stimulated cultured ovary with AVT and IT in vitro. As expected, both cox 2 and itr 1 were upregulated by AVT and IT treatments; however, AVT treatment resulted in faster and stronger transcriptional regulation of $\operatorname{cox} 2$ and itr 1 than that of IT. Measurement of $\mathrm{PGF}_{2 \mathrm{a}}$ concentrations showed that AVT was more efficient inducer of PG synthesis. In humans, OT regulates the expression of its own mRNA through the transcription factor nuclear factor kappa B (NF- $\mathrm{KB})$ and PGs in a positive feedback mechanism. A previous clinical analysis showed that the expression of cox 2 and otr was high in women with high NF- $\kappa B$ activity (63). Similar results were obtained in primary human amnion epithelial cells incubated with IL-1 $\beta$, which is an inflammatory factor that activates $\mathrm{NF}-\kappa \mathrm{B}$, resulting in rapid upregulation of otr (28). Similarly, our results suggested a 
A

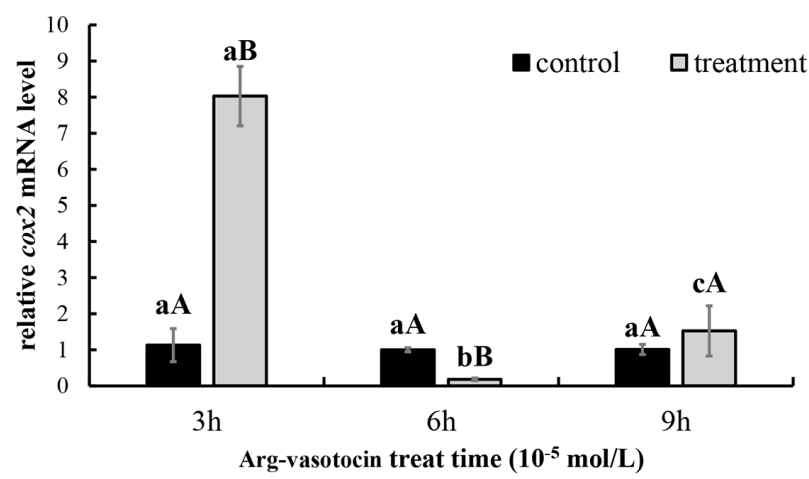

C

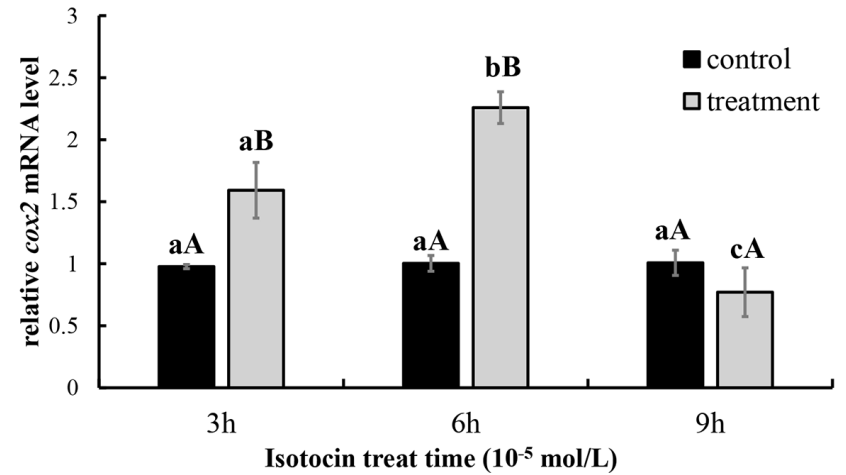

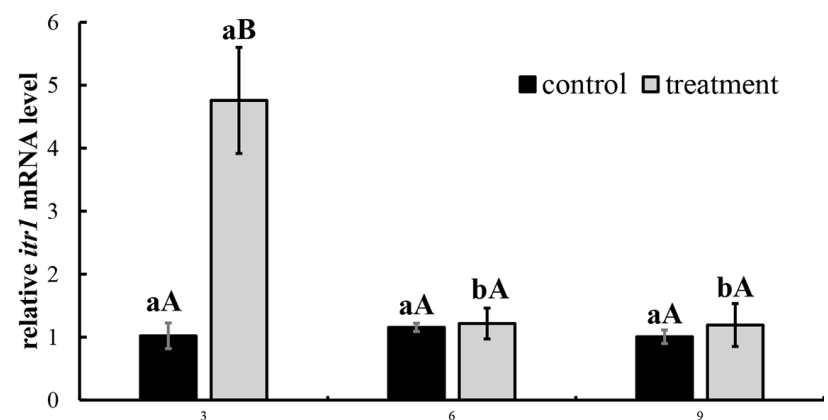

Arg-vasotocin treat time $\left(10^{-5} \mathrm{~mol} / \mathrm{L}\right)$

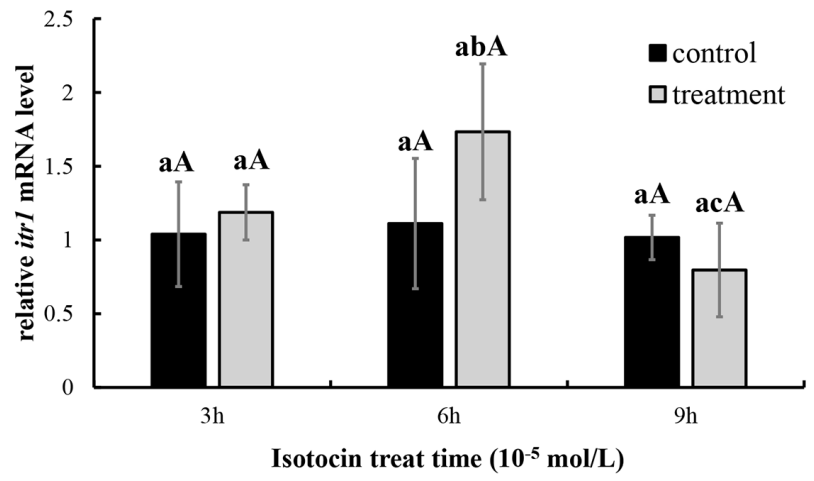

FIGURE 7 | Time-dependent effects of AVT and IT on the expression of cox2 and itr1 mRNAs in guppy ovary fragments. The levels of the cox2 and itr1 mRNAs were measured using qPCR $(n=5)$. (A, B) Ovary fragments were incubated with AVT $\left(10^{-5} \mathrm{~mol} / \mathrm{L}\right)$ for 3,6 , or $9 \mathrm{~h}$. (C, D) Ovary fragments were incubated with IT $\left(10^{-5} \mathrm{~mol} / \mathrm{L}\right)$ for 3,6 , or $9 \mathrm{~h}$. The results are presented as the mean \pm SEM and as fold changes in the expression levels versus the corresponding controls. Different capital letters indicate significant differences at the same time points between the treatment and control groups $(P<0.05)$. Different lowercase letters indicate significant differences in the corresponding control or treatment groups $(P<0.05)$.

conserved parturition mechanism in mammals and live bearing teleost guppies. Notably, OT had opposite effects on luteal phase mares; however, the levels of a series of enzymes involved in PG synthesis, including cox 2 , were decreased after OT administration (30). The data of dual ISH indicated that itr localization followed a stage-related expression pattern. This result may explain why OT/IT has different functions in ovaries at different developmental stages.

In vivo injection of $\mathrm{PGF}_{2 \mathrm{a}}$ was performed to confirm its function in inducing preterm parturition. Similar to a previous study (14), prematurely delivered fry had a shorter body length and larger yolk sac. Interestingly, the results of this study indicated that a high concentration (500 ng/g), but not a low concentration (50 ng/g), of AVT can induce premature birth in guppy. However, in the present study, injection of AVT (500 ng/g) did not induce premature birth, and direct injection of $\mathrm{PGF}_{2 \mathrm{a}}$ was able to significantly induce premature birth. The differences between individuals and gestation period may be responsible for variability of the results. A study on teleost ovulation reported that $\mathrm{PGF}_{2 \mathrm{a}}$ was more effective than AVT in inducing ovulation in a dose- and duration-dependent manner (64). Considering that stimulation of guppy with AVT increased $\mathrm{PGF}_{2 \mathrm{a}}$ concentration and did not activate premature birth, $\mathrm{PGF}_{2 \mathrm{a}}$ may be more effective than AVT in induction of delivery because AVT is located upstream in the positive feedback regulation of PG synthesis (luteinizing hormone (human chorionic gonadotropin) > 17,20 $\beta$-dixydroxy-4pregnen-3-on (DP) $<>$ AVT $>$ PGs $>$ final oocyte maturation (FOM)/ovulation) (64). The results also revealed that $\mathrm{PGF}_{2 \mathrm{a}}$ may play a crucial role in ovoviviparous teleost parturition, similar to other live bearing species, considering the function of this PG in mammalian myometrium contraction and in follicular apoptosis in teleosts $(3,60)$. The presence of immature dead larval fish confirmed the effect of $\mathrm{PGF}_{2 \mathrm{a}}$ on the unnatural induction of parturition in guppies.

In summary, the present study is the first to identify and characterize IT, AVT and ITRs in guppies. The results of the present study contributed to elucidation of direct effects of AVT and IT on cox 2 expression and subsequent induction of PG production in guppy mediated by CRE signaling, resulting in premature delivery. Our findings suggest that AVT functions as a more efficient factor that participates in parturition of live bearing teleost guppy by stimulating PG synthesis by upregulating $\operatorname{cox} 2$ expression. 


\section{early vitellogenesis stage oocyte}
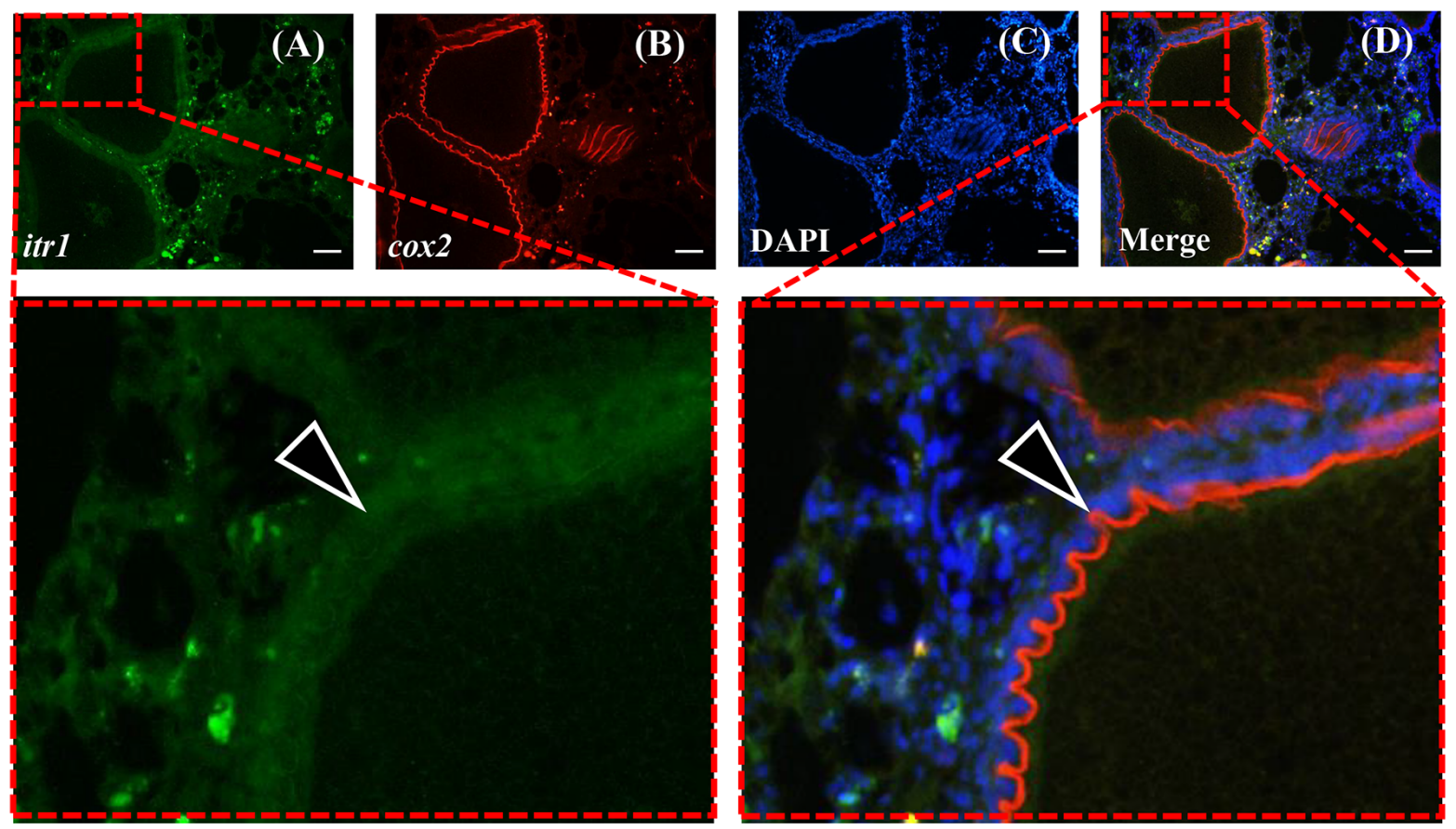

late vitellogenesis stage oocyte
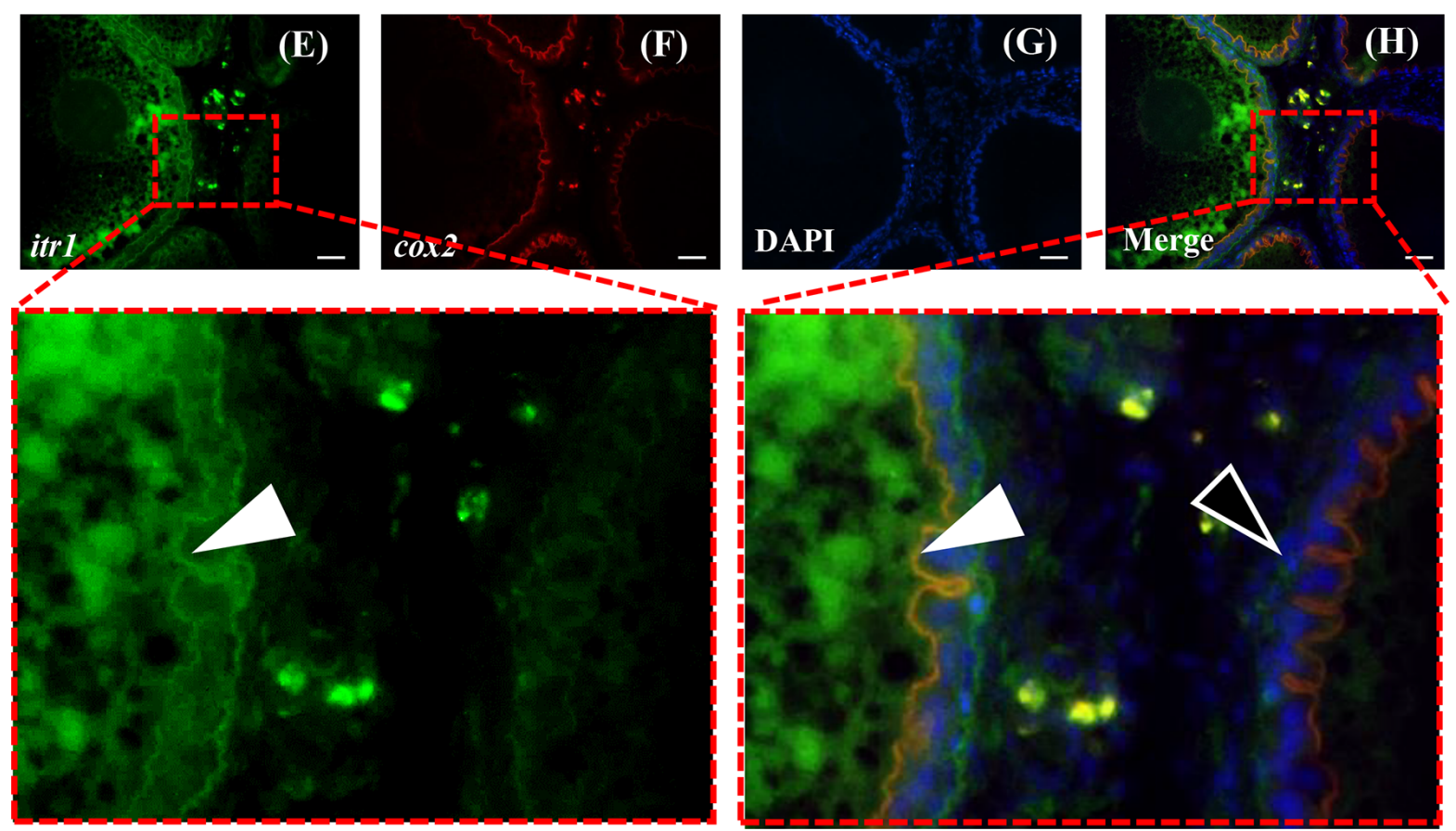

FIGURE 8 | Dual-fluorescence ISH for itr1 (green, stained with Alexa Fluor 488) and cox2 (red, stained with Alexa Fluor 594) in guppy ovaries at different developmental stages. (A-D) ISH staining in the early vitellogenesis stage. (E-H) ISH staining in the late vitellogenesis stage. The itr1 signal overlapping with the cox2 signal in the late vitellogenesis stage in the follicular cell layer is indicated by white arrowheads. The single cox 2 signal in the early vitellogenesis stage in the follicular layer is indicated by open arrowheads. Nuclei were stained with DAPI (blue). Scale bar, $20 \mu \mathrm{m}$. 


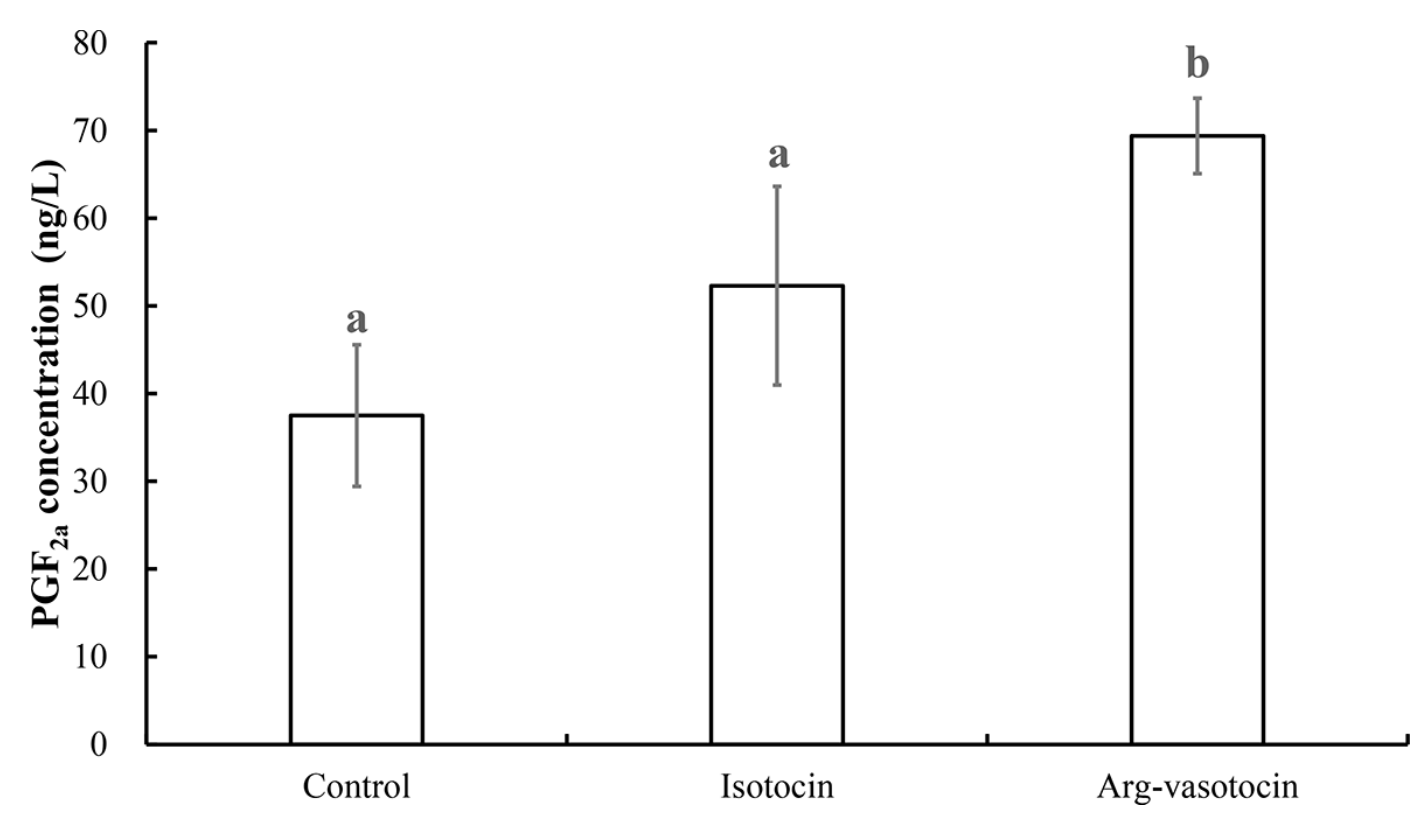

FIGURE 9 | Measurement of PGF $_{2 a}$ concentrations after IP injections of IT $(1 \mu \mathrm{g} / \mathrm{g})$, AVT $(1 \mu \mathrm{g} / \mathrm{g})$ or the same volume of saline (control). Eight individuals were analyzed in each group. Different lowercase letters indicate significant differences between the treatment groups $(P<0.05)$.

$\mathrm{PGF}_{2 \mathrm{a}}$ injection
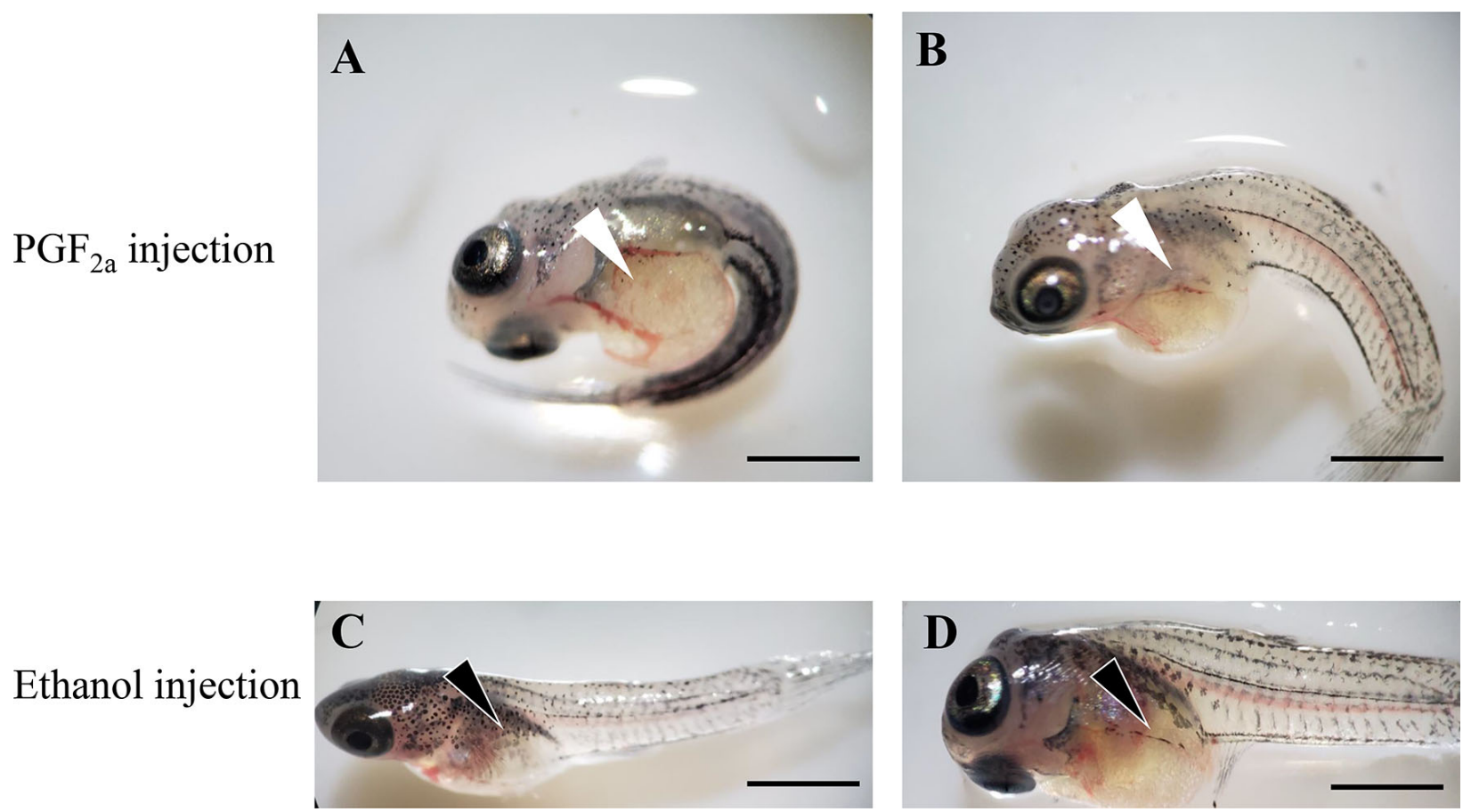

FIGURE 10 | Offspring of pregnant guppies injected with $\mathrm{PGF}_{2 a}(1,000 \mathrm{ng} / \mathrm{g})$ or ethanol (vehicle control). The $\mathrm{PGF}_{2 \mathrm{a}}$ injection induced premature parturition, and larval fish presented larger yolk sac (white arrowheads) and curly bodies (A, B). $n=5$. Normal larval fish from ethanol-injected pregnant guppies presented a regular yolk sac (black arrowheads) and stretched bodies (C, D). $n=5$. Scale bar, $1 \mathrm{~mm}$. 


\section{DATA AVAILABILITY STATEMENT}

The data sets presented in this study can be found in online repositories. The names of the repository/repositories and accession number(s) can be found in the article/ Supplementary Material.

\section{ETHICS STATEMENT}

The animal study was reviewed and approved by Animal Research and Ethics Committees of Ocean University of China.

\section{AUTHOR CONTRIBUTIONS}

HSW, JFL, YL, and XQ designed the study. LKL performed the experiment. LKL, XJW, YJY, and JSL participated in the sample collection. LKL wrote the manuscript, and XQ provided feedback

\section{REFERENCES}

1. Gimpl G, Fahrenholz F. The oxytocin receptor system: structure, function, and regulation. Physiol Rev (2001) 81(2):629-83. doi: 10.1152/physrev.2001.81.2.629

2. Duffield A, McKenzie C, Carvalho B, Ramachandran B, Yin V, El-Sayed YY, et al. Effect of a High-Rate Versus a Low-Rate Oxytocin Infusion for Maintaining Uterine Contractility During Elective Cesarean Delivery: A Prospective Randomized Clinical Trial. Anesthesia analgesia (2017) 124 (3):857-62. doi: 10.1213/ane.0000000000001658

3. Kim SH, Riaposova L, Ahmed H, Pohl O, Chollet A, Gotteland J-P, et al. Oxytocin Receptor Antagonists, Atosiban and Nolasiban, Inhibit Prostaglandin F2 $\alpha$-induced Contractions and Inflammatory Responses in Human Myometrium. Sci Rep (2019) 9(1):5792. doi: 10.1038/s41598-01942181-2

4. Lavie A, Shinar S, Hiersch L, Ashwal E, Yogev Y, Aviram A. Uterine electrical activity, oxytocin and labor: translating electrical into mechanical. Arch gynecology obstetrics (2018) 297(6):1405-13. doi: 10.1016/j.ajog.2016.11.678

5. Sakamoto T, Nishiyama Y, Ikeda A, Takahashi H, Hyodo S, Kagawa N, et al. Neurohypophysial Hormones Regulate Amphibious Behaviour in the Mudskipper Goby. PloS One (2015) 10(7):e0134605. doi: 10.1371/ journal.pone.0134605 PubMed PMID: 26230718

6. Ramsey ME, Fry D, Cummings ME. Isotocin increases female avoidance of males in a coercive mating system: Assessing the social salience hypothesis of oxytocin in a fish species. Hormones Behav (2019) 112:1-9. doi: 10.1016/ j.yhbeh.2019.03.001

7. O'Connell LA, Matthews BJ, Hofmann HA. Isotocin regulates paternal care in a monogamous cichlid fish. Horm Behav (2012) 61(5):725-33. doi: 10.1016/ j.yhbeh.2012.03.009

8. Almeida O, Gozdowska M, Kulczykowska E, Oliveira RF. Brain levels of arginine-vasotocin and isotocin in dominant and subordinate males of a cichlid fish. Hormones Behav (2012) 61(2):212-7. doi: 10.1016/ j.yhbeh.2011.12.008

9. Cunha-Saraiva F, Balshine S, Gozdowska M, Kulczykowska E, Wagner RH, Schaedelin FC. Parental care and neuropeptide dynamics in a cichlid fish Neolamprologus caudopunctatus. Hormones Behav (2019) 116:104576. doi: 10.1016/j.yhbeh.2019.104576

10. Kleszczyńska A, Sokołowska E, Kulczykowska E. Variation in brain arginine vasotocin (AVT) and isotocin (IT) levels with reproductive stage and social status in males of three-spined stickleback (Gasterosteus aculeatus). Gen Comp Endocrinol (2012) 175(2):290-6. doi: 10.1016/j.ygcen.2011.11.022

11. Pickford GE, Strecker EL. The spawning reflex response of the killifish, Fundulus heteroclitus: isotocin is relatively inactive in comparison with on the manuscript and edited the article All authors contributed to the article and approved the submitted version.

\section{FUNDING}

This study was supported by grants from the National Key R\&D Program of China (2018YFD0901204) and The National Natural Science Foundation of China (41976089 and 41676126).

\section{SUPPLEMENTARY MATERIAL}

The Supplementary Material for this article can be found online at: https://www.frontiersin.org/articles/10.3389/fendo.2021. 617580/full\#supplementary-material

Supplementary Video 1 | Representative video showing the first premature parturition of guppies injected with $\mathrm{PGF}_{2 a}(1,000 \mathrm{ng} / \mathrm{g})$; parturition occurred at $21 \mathrm{~s}$.

arginine vasotocin. Gen Comp Endocrinol (1977) 32(2):132-7. doi: 10.1016/ 0016-6480(77)90143-5

12. Muchlisin ZA, Arfandi G, Adlim M, Fadli N, Sugianto S. Induced spawning of seurukan fish, Osteochilus vittatus (Pisces: Cyprinidae) using ovaprim, oxytocin and chicken pituitary gland extracts. Aquaculture Aquarium Conserv Legislation (2014) 7(5):412-8.

13. Nainggolan M, Napitupulu H, Sipayung K, Sukendi D. The Effect of Ovaprim Injections Combination With Oxytocin on Ovulation Stimulation and The Quality of Egg Hoven's Carp (Leptobarbus Hoevenii Blkr). Int J Appl Environ Sci (2018) 13(7):621-32.

14. Venkatesh B, Tan CH, Lam TJ. Prostaglandins and teleost neurohypophyseal hormones induce premature parturition in the guppy, Poecilia reticulata. Gen Comp Endocrinol (1992) 87(1):28-32. doi: 10.1016/0016-6480(92)90146-b

15. The role of arginine vasotocin in teleost fish osmoregulation. Symp Soc Exp Biol (2002) 2002(54):83-95. doi: 10.2307/2332794 .

16. Jurkevich A, Grossmann R, Balthazart J, Viglietti-Panzica C. Gender-related changes in the avian vasotocin system during ontogeny. Microscopy Res Technique (2001) 55(1):27-36. doi: 10.1002/jemt.1153

17. Balment R, Lu W, Weybourne E, Warne J. Arginine vasotocin a key hormone in fish physiology and behaviour: a review with insights from mammalian models. Gen Comp Endocrinol (2006) 147(1):9-16. doi: 10.1016/j.ygcen.2005.12.022

18. Foran CM, Bass AH. Preoptic AVT immunoreactive neurons of a teleost fish with alternative reproductive tactics. Gen Comp Endocrinol (1998) 111 (3):271-82. doi: 10.1006/gcen.1998.7113

19. Carneiro LA, Oliveira RF, Canario AV, Grober M. The effect of arginine vasotocin on courtship behaviour in a blenniid fish with alternative reproductive tactics. Fish Physiol Biochem (2003) 28(1-4):241-3. doi: 10.1023/b:fish.0000030542.31395.8a

20. Ramallo MR, Grober M, Cánepa MM, Morandini L, Pandolfi M. Argininevasotocin expression and participation in reproduction and social behavior in males of the cichlid fish Cichlasoma dimerus. Gen Comp Endocrinol (2012) 179(2):221-31. doi: 10.1016/j.ygcen.2012.08.015

21. Acher R, Chauvet J. The neurohypophysial endocrine regulatory cascade: precursors, mediators, receptors, and effectors. Front Neuroendocrinol (1995) 16(3):237-89. doi: 10.1006/frne.1995.1009

22. Song Z, Albers HE. Cross-talk among oxytocin and arginine-vasopressin receptors: Relevance for basic and clinical studies of the brain and periphery. Front Neuroendocrinol (2018) 51:14-24. doi: 10.1016/j.yfrne.2017.10.004

23. Hicks C, Ramos L, Reekie T, Misagh G, Narlawar R, Kassiou M, et al. Body temperature and cardiac changes induced by peripherally administered oxytocin, vasopressin and the non-peptide oxytocin receptor agonist WAY 267,464: a biotelemetry study in rats. Br J Pharmacol (2014) 171(11):2868-87. doi: $10.1111 /$ bph.12613 
24. Ramos L, Hicks C, Caminer A, Couto K, Narlawar R, Kassiou M, et al. MDMA ('Ecstasy'), oxytocin and vasopressin modulate social preference in rats: A role for handling and oxytocin receptors. Pharmacol Biochem Behav (2016) 150:115-23. doi: 10.1016/j.pbb.2016.10.002

25. Kawamata M, Mitsui-Saito M, Kimura T, Takayanagi Y, Yanagisawa T, Nishimori K. Vasopressin-induced contraction of uterus is mediated solely by the oxytocin receptor in mice, but not in humans. Eur J Pharmacol (2003) 472(3):229-34. doi: 10.1016/s0014-2999(03)01914-9

26. Arrowsmith S, Wray S. Oxytocin: its mechanism of action and receptor signalling in the myometrium. J Neuroendocrinol (2014) 26(6):356-69. doi: $10.1111 /$ jne. 12154

27. Kim SH, Bennett PR, Terzidou V. Advances in the role of oxytocin receptors in human parturition. Mol Cell Endocrinol (2017) 449:56-63. doi: 10.1016/ j.mce.2017.01.034

28. Terzidou V, Blanks AM, Kim SH, Thornton S, Bennett PR. Labor and inflammation increase the expression of oxytocin receptor in human amnion. Biol Reprod (2011) 84(3):546-52. doi: 10.1095/biolreprod.110.086785

29. Sztachelska M, Ponikwicka-Tyszko D, Sokolowska G, Anisimowicz S, Czerniecki J, Lebiedzinska W, et al. Oxytocin antagonism reverses the effects of high estrogen levels and oxytocin on decidualization and cyclooxygenase activity in endometrial tissues. Reprod BioMedicine Online (2019) 39(5):737-44. doi: 10.1016/j.rbmo.2019.06.002

30. Rebordão MR, Galvão A, Pinto-Bravo P, Pinheiro J, Gamboa S, Silva E, et al. Endometrial prostaglandin synthases, ovarian steroids, and oxytocin receptors in mares with oxytocin-induced luteal maintenance. Theriogenology (2017) 87:193-204. doi: 10.1016/j.theriogenology.2016.08.028

31. Gómez-Abellán V, Sepulcre MP. The role of prostaglandins in the regulation of fish immunity. Mol Immunol (2016) 69:139-45. doi: 10.1016/ j.molimm.2015.09.022

32. Sugimoto $\mathrm{Y}$, Inazumi $\mathrm{T}$, Tsuchiya S. Roles of prostaglandin receptors in female reproduction. J Biochem (2015) 157(2):73-80. doi: 10.1093/jb/mvu081

33. De Rensis F, Saleri R, Tummaruk P, Techakumphu M, Kirkwood R. Prostaglandin F2 $\alpha$ and control of reproduction in female swine: a review. Theriogenology (2012) 77(1):1-11. doi: 10.1016/j.theriogenology.2011.07.035

34. Davis TL, Bott RC, Slough TL, Bruemmer JE, Niswender GD. Progesterone inhibits oxytocin-and prostaglandin F2alpha-stimulated increases in intracellular calcium concentrations in small and large ovine luteal cells. Biol Reprod (2010) 82(2):282-8. doi: 10.1095/biolreprod.109.079970

35. Kuradomi RY, Batlouni SR. PGF $2 \alpha$ and gonadal steroid plasma levels of successful and unsuccessful spawning Piaractus mesopotamicus (Teleostei, Characiformes) females. Aquaculture Int (2018) 26(4):1083-94. doi: 10.1007/ s10499-018-0269-8

36. Stacey N. Effects of indomethacin and prostaglandins on the spawning behaviour of female goldfish. Prostaglandins (1976) 12(1):113-26. doi: 10.1016/s0090-6980(76)80010-x

37. Sorensen PW, Appelt C, Stacey NE, Goetz FW, Brash AR. High levels of circulating prostaglandin $\mathrm{F} 2 \alpha$ associated with ovulation stimulate female sexual receptivity and spawning behavior in the goldfish (Carassius auratus). Gen Comp Endocrinol (2018) 267:128-36. doi: 10.1016/j.ygcen.2018.06.014

38. Zhang Z, Wen H, Li Y, Li Q, Li W, Zhou Y, et al. TAC3 gene products regulate brain and digestive system gene expression in the spotted sea bass (Lateolabrax maculatus). Front Endocrinol (2019) 10:556:556. doi: 10.3389/fendo.2019.00556

39. Bendtsen JD, Nielsen H, von Heijne G, Brunak S. Improved prediction of signal peptides: SignalP 3.0. J Mol Biol (2004) 340(4):783-95. doi: 10.1016/ j.jmb.2004.05.028

40. Southey BR, Amare A, Zimmerman TA, Rodriguez-Zas SL, Sweedler JV. NeuroPred: a tool to predict cleavage sites in neuropeptide precursors and provide the masses of the resulting peptides. Nucleic Acids Res (2006) 34 (suppl_2):W267-72. doi: 10.1093/nar/gkl161

41. Thompson JD, Higgins DG, Gibson TJ. CLUSTAL W: improving the sensitivity of progressive multiple sequence alignment through sequence weighting, position-specific gap penalties and weight matrix choice. Nucleic Acids Res (1994) 22(22):4673-80. doi: 10.1007/978-1-4020-6754-9_3188

42. Tamura K, Stecher G, Peterson D, Filipski A, Kumar S. MEGA6: molecular evolutionary genetics analysis version 6.0. Mol Biol Evol (2013) 30(12):2725-9. doi: $10.2307 / 2413665$

43. Qi X, Zhou W, Wang Q, Guo L, Lu D, Lin H. Gonadotropin-Inhibitory Hormone, the Piscine Ortholog of LPXRFa, Participates in $17 \beta$-Estradiol
Feedback in Female Goldfish Reproduction. Endocrinology (2017) 158 (4):860-73. doi: 10.1210/en.2016-1550

44. Kanda S, Karigo T, Oka Y. Steroid sensitive kiss2 neurones in the goldfish: evolutionary insights into the duplicate kisspeptin gene-expressing neurones. J Neuroendocrinol (2012) 24(6):897-906. doi: 10.1111/j.1365-2826.2012.02296.x

45. Qi X, Zhou W, Lu D, Wang Q, Zhang H, Li S, et al. Sexual dimorphism of steroidogenesis regulated by $\mathrm{GnIH}$ in the goldfish, Carassius auratus. Biol Reprod (2013) 88(4):81-7. doi: 10.1095/biolreprod.112.105114

46. Barberis C, Mouillac B, Durroux T. Structural bases of vasopressin/oxytocin receptor function. J Endocrinol (1998) 156(2):223. doi: 10.1677/joe.0.1560223

47. Huffman LS, O'Connell LA, Kenkel CD, Kline RJ, Khan IA, Hofmann HA. Distribution of nonapeptide systems in the forebrain of an African cichlid fish, Astatotilapia burtoni. J Chem Neuroanat (2012) 44(2):86-97. doi: 10.1016/ j.jchemneu.2012.05.002

48. Ribeiro D, Nunes AR, Gliksberg M, Anbalagan S, Levkowitz G, Oliveira RF. Oxytocin receptor signalling modulates novelty recognition but not social preference in zebrafish. J Neuroendocrinol (2020) 32(4):e12834. doi: 10.1111/ jne.12834

49. Pasquier J, Cabau C, Nguyen T, Jouanno E, Severac D, Braasch I, et al. Gene evolution and gene expression after whole genome duplication in fish: the PhyloFish database. BMC Genomics (2016) 17(1):1-10. doi: 10.1186/s12864016-2709-z

50. Martos-Sitcha JA, Fuentes J, Mancera JM, Martínez-Rodríguez G. Variations in the expression of vasotocin and isotocin receptor genes in the gilthead sea bream Sparus aurata during different osmotic challenges. Gen Comp Endocrinol (2014) 197:5-17. doi: 10.1016/j.ygcen.2013.11.026

51. Lagman D, Daza DO, Widmark J, Abalo XM, Sundström G, Larhammar D. The vertebrate ancestral repertoire of visual opsins, transducin alpha subunits and oxytocin/vasopressin receptors was established by duplication of their shared genomic region in the two rounds of early vertebrate genome duplications. BMC evolutionary Biol (2013) 13(1):1-21. doi: 10.1186/1471-2148-13-238

52. Hasunuma I, Toyoda F, Okada R, Yamamoto K, Kadono Y, Kikuyama S. Roles of arginine vasotocin receptors in the brain and pituitary of submammalian vertebrates. Int Rev Cell Mol Biol 304. Elsevier (2013) 304:191-225. doi: 10.1016/B978-0-12-407696-9.00004-X

53. Caldwell H, Young H. Oxytocin and Vasopressin: Genetics and Behavioral Implications. In: Lajtha A., Lim R, editors. Handbook of Neurochemistry and Molecular Neurobiology. Springer, Boston, MA (2006). doi: 10.1007/978-0387-30381-9_25

54. Albers HE. Species, sex and individual differences in the vasotocin/vasopressin system: relationship to neurochemical signaling in the social behavior neural network. Front Neuroendocrinol (2015) 36:49-71. doi: 10.1016/j.yfrne.2014.07.001

55. Hawtin SR, Wesley VJ, Parslow RA, Patel S, Wheatley M. Critical role of a subdomain of the $\mathrm{N}$-terminus of the $\mathrm{V} 1 \mathrm{a}$ vasopressin receptor for binding agonists but not antagonists; functional rescue by the oxytocin receptor Nterminus. Biochemistry (2000) 39(44):13524-33. doi: 10.1021/bi0013400

56. Thibonnier M, Coles P, Thibonnier A, Shoham M. The basic and clinical pharmacology of nonpeptide vasopressin receptor antagonists. Annu Rev Pharmacol Toxicol (2001) 41(1):175-202. doi: 10.1146/annurev.pharmtox.41.1.175

57. Duffy DM. Novel contraceptive targets to inhibit ovulation: the prostaglandin E2 pathway. Hum Reprod Update (2015) 21(5):652-70. doi: 10.1093/humupd/ dmv026

58. Crespo D, Goetz FW, Planas JV. Luteinizing hormone induces ovulation via tumor necrosis factor $\alpha$-dependent increases in prostaglandin $\mathrm{F} 2 \alpha$ in a nonmammalian vertebrate. Sci Rep (2015) 5(1):1-12. doi: 10.1038/srep14210

59. Martinović-Weigelt D, Mehinto AC, Ankley GT, Berninger JP, Collette TW, Davis JM, et al. Derivation and evaluation of putative adverse outcome pathways for the effects of cyclooxygenase inhibitors on reproductive processes in female fish. Toxicological Sci (2017) 156(2):344-61. doi: $10.1093 /$ toxsci/kfw257

60. Takahashi T, Hagiwara A, Ogiwara K. Prostaglandins in teleost ovulation: A review of the roles with a view to comparison with prostaglandins in mammalian ovulation. Mol Cell Endocrinol (2018) 461:236-47. doi: 10.1016/j.mce.2017.09.019

61. Joy K, Singh V. Functional interactions between vasotocin and prostaglandins during final oocyte maturation and ovulation in the catfish Heteropneustes fossilis. Gen Comp Endocrinol (2013) 186:126-35. doi: 10.1016/ j.ygcen.2013.02.043 
62. Hausmann H, Meyerhof W, Zwiers H, Lederis K, Richter D. Teleost isotocin receptor: structure, functional expression, mRNA distribution and phylogeny. FEBS Lett (1995) 370(3):227-30. doi: 10.1016/0014-5793(95)00832-T

63. Lim S, MacIntyre DA, Lee YS, Khanjani S, Terzidou V, Teoh T, et al. Nuclear factor kappa B activation occurs in the amnion prior to labour onset and modulates the expression of numerous labour associated genes. PloS One (2012) 7(4):e34707. doi: 10.1371/journal.pone.0034707

64. Joy KP, Singh V. Functional interactions between vasotocin and prostaglandins during final oocyte maturation and ovulation in the catfish Heteropneustes fossilis. Gen Comp Endocrinol (2013) 186:126-35. doi: 10.1016/j.ygcen.2013.02.043
Conflict of Interest: The authors declare that the research was conducted in the absence of any commercial or financial relationships that could be construed as a potential conflict of interest.

Copyright (C) $2021 \mathrm{Lyu}, \mathrm{Li}$, Wang, Yao, Li, Li, Wen and Qi. This is an open-access article distributed under the terms of the Creative Commons Attribution License (CC BY). The use, distribution or reproduction in other forums is permitted, provided the original author(s) and the copyright owner(s) are credited and that the original publication in this journal is cited, in accordance with accepted academic practice. No use, distribution or reproduction is permitted which does not comply with these terms. 